\title{
ELECTRICITY SAVINGS AMONG PARTICIPANTS THREE YEARS AFTER WEATHERIZATION IN BONNEVILLE'S 1986 RESIDENTIAL WEATHERIZATION PROGRAM
}

\author{
September 1990
}

Dennis L. White Marilyn A. Brown

Research Sponsored by the Office of Energy Resources Bonneville Power Administration

Prepared by the

Oak Ridge National Laboratory

Oak Ridge, Tennessee 37831-6285 operated by

MARTIN MARIETTA ENERGY SYSTEMS, INC.

for the

U.S. DEPARTMENT OF ENERGY

under contract DE-AC05-84OR21400 


\section{DEDICATION}

Cathryn Currier passed away June 4, 1990. This work is dedicated to Cathryn.

Cathryn was a program analyst with Tacoma Public Utilities. Her professionalism and competence were only two of her many extraordinary qualities.

Cathryn was an inspiring colleague. Those of us who are privileged to have known Cathiyn will always remember her strength and courage, as well as her genuine selflessness. Nothing mattered to her more than the health and happiness of others. Each of us would do well to be a little more like her.

Dennis L. White 
TABLE OF CONTENTS

LIST OF FIGURES $\ldots \ldots \ldots \ldots \ldots \ldots \ldots \ldots \ldots \ldots \ldots \ldots \ldots \ldots$

LIST OF TABLES $\ldots \ldots \ldots \ldots \ldots \ldots \ldots \ldots \ldots \ldots \ldots \ldots \ldots \ldots$

ABSTRACT $\ldots \ldots \ldots \ldots \ldots \ldots \ldots \ldots \ldots \ldots \ldots \ldots \ldots \ldots \ldots \ldots \ldots \ldots \ldots \ldots$

EXECUTIVE SUMMARY $\ldots \ldots \ldots \ldots \ldots \ldots \ldots \ldots \ldots \ldots \ldots \ldots \ldots \ldots$

1. INTRODUCTION $\ldots \ldots \ldots \ldots \ldots \ldots \ldots \ldots \ldots \ldots \ldots \ldots \ldots \ldots$

1.1 PURPOSE AND OUTLINE OF REPOKT $\ldots \ldots \ldots \ldots \ldots \ldots \ldots \ldots$

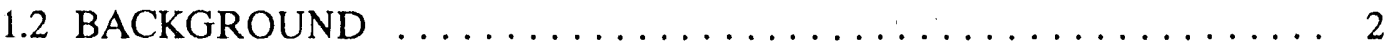

2. RESEARCH METHODS $\ldots \ldots \ldots \ldots \ldots \ldots \ldots \ldots \ldots \ldots \ldots \ldots \ldots$

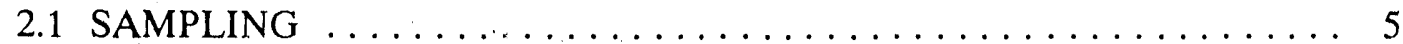

2.2 DATA COLLECTION AND SCREENING $\ldots \ldots \ldots \ldots \ldots \ldots \ldots \ldots$

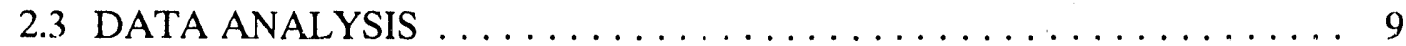

2.4 UTILITY WEIGHTS $\ldots \ldots \ldots \ldots \ldots \ldots \ldots \ldots \ldots \ldots \ldots \ldots \ldots$

3. MEASURES RECOMMENDED AND INSTALLED $\ldots \ldots \ldots \ldots \ldots \ldots \ldots$

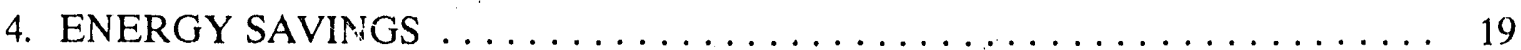

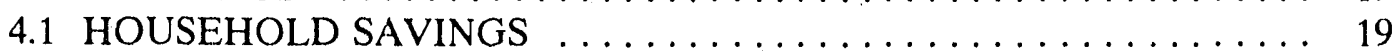

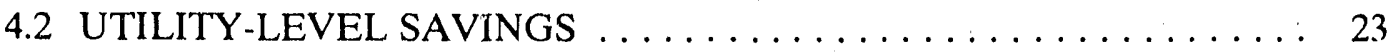

4.3 OVERALL PROGRAM SAVINGS ............... 29

5. SUMMARY AND CONCLUSIONS $\ldots \ldots \ldots \ldots \ldots \ldots \ldots \ldots \ldots$

APPENDIX A: BIAS TESTS $\ldots \ldots \ldots \ldots \ldots \ldots \ldots \ldots \ldots \ldots \ldots \ldots \ldots$

ACKNOWLEDGMENTS $\ldots \ldots \ldots \ldots \ldots \ldots \ldots \ldots \ldots \ldots \ldots \ldots \ldots$

REFERENCES ........................... 47 


\section{LIST OF FIGURES}

Figure 4.1. Annual gross electricity salvings for program participants and nonparticipants, onc. I wo, and three years after

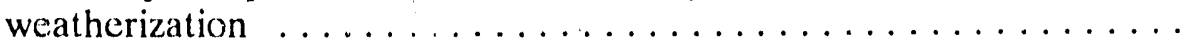

Figure 4.2. Comparison of audit-estimated swings with actu.l gross program electricity savings one year after weatherization ........ 22

Figure 4.3. NAC components for program participants and nonparticipants ... . . . . . . . . . . . . . . . . . . . . 29

Figure 4.4. Average program-wide gross electricity savings for program participants and nonparticipants (weighted)

Figure 4.5. Comparison of clectricity savings by participants in Bonneville's weatherization programs .............. 34 


\section{LIST OF TABLES}

Table 2.1. Data attrition and sample sizes $\ldots \ldots \ldots \ldots \ldots \ldots \ldots \ldots$

Table 2.2. Utility weights and participation rates for 1986 Long-Term RWP . . . 11

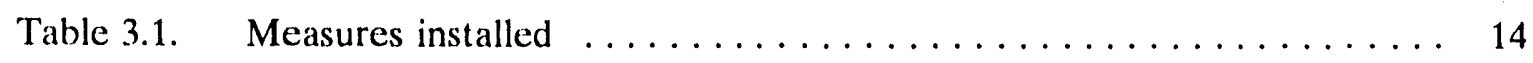

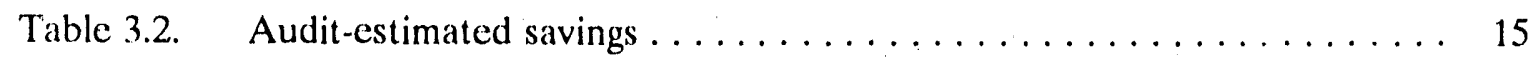

Table 3.3. Weatherization costs $\ldots \ldots \ldots \ldots \ldots \ldots \ldots \ldots \ldots \ldots \ldots \ldots$

Table 4.1. Comparison of weighted preretrofit normalized annual consumption by program participants and nonparticipants . . . . . 20

Table 4.2. Average weather-adjusted electricity consumption and gross electricity savings one year after weatherization, by utility ....... 24

Table 4.3. Average weather-adjusted electricity consumption and gross electricity savings two years after weatherization, by utility $\ldots \ldots \ldots 25$

Table 4.4. Average weather-adjusted electricity consumption and gross electricity savings three years after weatherization, by utility . . . . . 26

Table 4.5 . Average net electricity savings by utility $\ldots \ldots \ldots \ldots \ldots \ldots$

Table 4.6. Average net electricity savings and possible explanatory factors, by utility ...................... 28

Table 4.7. Average electricity savings for program participants and

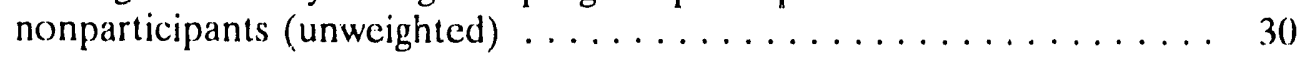

Table 4.8. Weighted average annual program-induced gross and net electricity savings for all postretrofit years . . . . . . . . . . 32

Table 4.9. Average annual electricity savings during postretrofit years . . . . . . 33

Table A.1. Data attrition and sample sizes (program summary) $\ldots \ldots \ldots \ldots \ldots 2$ 


\begin{abstract}
This study continues the series of evaluations of the Bonneville Power Administration's Long-Term Residential Weatherization Program (Long-Term RWP). Data were collected from households weatherized in 1986 under Bonneville's Data Gathering Project (DGP) and from a control group of nonparticipants. This study is an update of the original analysis (Schweitzer, Brown, and White 1989), which examined retrofit activities and costs, and electricity savings one and two yeais after participation in the 1986 Long-Term RWP. Specifically, this update examines electricity savings three years after weatherization. The households selected come from seven of the eight utilities examined in the original analysis.
\end{abstract}

It was shown in the original analysis that in the 1986 Long-Term RWP, $83 \%$ of auditrecommended measures were installed, approximately the same installation rate attained by participants in the Residential Weatherization Pilot Program (1980-82), the Interim RWP (1982-83), and the 1985 Long-Term RWP. Also, as in previous program years, the installation rate was higher for recornmended measures with greater estimated energy savings. Although Bonneville's retrofit costs have remained fairly constant over ume, total retrofit costs have increased from $\$ 1,700$ per house in 1982 to $\$ 2,400$ in 1986 (in 1986-\$); the additional costs have been absorbed by participating households and utilities. Similarly Bonneville's cost per estimated kWh of first-year electricity savings has stayed at about 27 cents $/ \mathrm{kWh}$ while the average total cost has risen from $28 \mathrm{cents} / \mathrm{kWh}$ in 1982 to $44 \mathrm{cents} / \mathrm{kWh}$ in 1986 (in 1986-\$).

The characteristic difference in preprogram electricity consumption between participant and control group households is becoming less distinct. In the Bonneville Residential Weatherization Pilot Program conducted during 1980 through 1982, participating households included in the evaluation used $30,280 \mathrm{kWh} /$ year in the preweatherization year while nonparticipants used $25,780 \mathrm{kWh} /$ year. Thus, participants used nearly $18 \%$ more electricity than nonparticipants. In the 1986 Long-Term RWP, participants used $24,310 \mathrm{kWh}$ (weighted) in the preretrofit year while the control group households used an average of $22,270 \mathrm{kWh}$ (weighted). Participants used only $9 \%$ more electricity than nonparticipants. From the Pilot Program to the 1986 Long-Term DGP, the difference in preprogram electricity consumption between participants and control group households declined by almost $50 \%$.

For the 1986 Long-Term RWP overall, savings experienced by participants were substantial. During the first year after weatherization, weighted net savings averaged 3,060 $\mathrm{kWh}$, or almost $13 \%$ of the previous year's energy consumption for the updated sample. In the second postweatherization year, a weighted average of $2,112 \mathrm{kWh}$ was saved, amounting to $9 \%$ of preweatherization energy use. In the third postweatherization year, a net weighted average of $2,140 \mathrm{kWh}$ was saved, $9 \%$ of preweatherization electricity use.

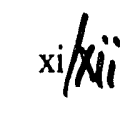




\section{EXECUTTVE SUMMARY}

To ensure proper assessment of its weatherization activities, the Bonneville Power Administration (Bonneville) has examined several cohorts of participants in various phases of its Long-Term Residential Weatherization Program (Long-Term RWP). Beginning in 1980, energy savings one, two, and three years after program participation have been evaluated. This study, which continues the series of Bonneville's ongoing evaluation of weatherization activities, examines electricity savings three years after weatherization in the 1986 Long-Term RWP.

The sample of participants for this study was selected by Bonneville from its Data Gathering Project (DGP) database, which included 12 utilities from the region's three climate zones and four states. Five of these DGP utilities were excluded from the present analysis because three participated in Bonneville's Wood Heat Displacement Program (WHDP), one utility operated a program that deviated from the Long-Term RWP, and the number of participating households available for analysis in one utility declined to zero. Data for this update were collected for 252 participants and 688 nonparticipants with at least three complete years of postretrofit electricity billings; these households are a subset of the households that had been included in the original two-year evaluation.

Electricity bills were weather-adjusted using the Princeton Scorekeeping Method (PRISM). Normalized Annual Consumption (NAC) was calculated for each participant and control household for which data were available. Gross energy savings were calculated by subtracting a household's NAC for each postretrofit year (1986-87, 1987-88, and 1988-89) from its preretrofit NAC (1985-86). Household level data were aggregated and examined at the utility level allowing the calculation of average net savings, which is the difference between gross savings by nonparticipants and participants. Utility-level data were then weighted, based on the extent of each utility's participation in the Long-Term RWP in 1986, to allow the identification of overall program savings.

Findings are summarized below:

- The characteristic difference in preprogram electricity consumption between participant and control group households is becoming less distinct. In the Bonneville Residential Weatherization Pilot Program conducted during 1980 through 1982, participating houscholds included in the evaluation used $30,280 \mathrm{kWh} / \mathrm{year}$ in the preweatherization year while nonparticipants used $25,780 \mathrm{kWh} /$ year. Thus, participants used nearly $18 \%$ more electricity than nonparticipants. In the 1986 Long- 
Term RWP, participants used $24,310 \mathrm{kWh}$ (weighted) in the preretrofit year while the control group households used an average of $22,270 \mathrm{kWh}$ (weighted). Participants used only $9 \%$ more electricity than nonparticipants. From the Pilot Program to the 1986 Long-Term DGP, the difference in preprogram electricity consumption between participants and control group households declined by almost $50 \%$.

- In $1986,83 \%$ of audit-recommended measures were installed by program participants, approximately the same percentage as in previous years. The installation rate was higher for recommended measures with greater estimated energy savings - a pattern that was found in evaluations of previous program participants. Consistent with this conclusion, ceiling, floor, wall, and duct insulation were installed in almost all of the homes that needed it, and each of these insulation measures offered significant estimated savings. In contrast, caulking and weatherstripping were the two measures with the greatest disparity between rates of recommendation and installation, and they both offered only modest energy savings.

- For the 1986 Long-Term RWP overall, savings experienced by 1986 participants were substantial. During the first year after weatherization, weighted net savings averaged $3,060 \mathrm{kWh}$, or $13 \%$ of the previous year's energy consumption. In the second postweatherization year, a weighted average of $2,112 \mathrm{kWh}$ was saved, amounting to $9 \%$ of preweatherization energy use. In the third postweatherization year, a net weighted average of $2,140 \mathrm{kWh}$ was saved, amounting to $9 \%$ of preweatherization electricity use.

- The actual amount of energy saved by participating households varied widely in all three postweatherization years and was not closely related to audit-estimated savings. Relatively little of the variation in household performance was explained by preweatherization energy use, total weatherization costs, climate, and the installation of various energy conservation measures. This indicates that other factors, such as family composition and income, structural characteristics, changes in thermostat settings, and changes in the use of supplemental heat sources over time - in both participant and control groups - may be important in predicting the energy impacts of residential energy conservation programs.

- At the utility level, average gross savings for the 1986 cohort were positive for participants and negative for nonparticipants in the majority of cases. Wirhile substantial differences were observed among utilities in the amount of energy saved, these could not be explained by differences in average per capita income, recent changes in electricity rates, and climatic conditions (represented by long-run heating degree days). In addition to differences between utilities, substantial differences were also identified within utilities in terms of the amount of energy saved from one year to the next. 


\section{INTRODUCTION}

Over the past decade, most gas and electric utilities in the United States have offered free on-site home energy audits to their residential customers as part of the federal Residential Conservation Service (U.S. Congress 1978). The audits are often supplemented by financial incentives to encourage households to install recommended :etrofit measures. The underlying assumption of these andit and weatherization programs is that installation of retrofit measures will lead to substantial reductions in residential energy use, and that the value of these savings will justify the utility and household costs of implementation.

Tests of this assumption have typically been short-term in nature, examining homes that have participated over a one- or two-year period, and limiting their analysis of energy savings to a single year of postprogram consumption. The results, therefore, do not reflect the influence of various "life-cycle" phenomena, including changes in the nature of households that participate in programs over time, and changes in the performance of weatherization measures as they age. When conservation resources are being purchased to offset supply resources over an extended planning period, it is important to analyze the durability of program performance.

To ensure proper assessment of its weatherization program activities, the Bonneville Power Administration (Bonneville) has examined several cohorts of program participants, beginning in 1980, and has looked at energy savings one, two, and three years after participation. This study represents the latest addition to Bonneville's continuing series of weatherization evaluation studies (Goeltz, Hirst, and Trumble 1986; Haeri 1988; Hirst, et al. 1983a; Hirst, White, and Goeltz 1985; Hirst, et al. 1985; Horowitz, Bronfman, and Lerman 1987; Haeri 1988; Schweitzer, Brown, and White 1989).

\subsection{PURPOSE AND OUTLINE OF REPOR'T}

The purpose of this study is to provide an impact evaluation of Bonneville's 1986 Long-Term Residential Weatherization Program (Long-Term RWP) three years after weatherization. The evaluation rcviews the measures installed by the program and the actual electricity saved by participants. The results of prior evaluations, especially the original evaluation of the 1986 Long-Term RWP, provide a context and a comparison within which the present results are analyzed. 
The rest of Chapter 1 provides a history and brief description of Bonneville's RWP. Chapter 2 describes the research methods used in this update, including data collection and screening techniques, and data analysis methods. Chapter 3 begins the presentation of results, reviewing the services recommended and delivered by the Long-Term RWP to its 1986 participants. Chapter 4 focuses on energy savings, beginning with household-level savings, moving to utility-level savings, and ending with a discussion of overall program costs and savings. The report concludes with a summary and interpretation of findings, and suggestions for further research (Chapter 5).

\subsection{BACKGROUND}

Bonneville's residential weatherization efforts were initiated in response to a 1980 federal law that greatly expanded Bonneville's responsibilities for energy planning in the Pacific Northwest (U.S. Congress 1980). The original intent of the program was to retrofit 300,000 homes and generate an annual energy savings of 1.5 million MWh during its 10 -year lifetime at a cost of $\$ 480$ million (Bonneville 1982a and $b$ ).

Bonneville launched the Residential Weatherization Pilot Program in 1980 (Bonneville 1980). The Pilot Program was operated through 11 small public utilities located in Idaho, western Montana, Oregon, and Washington, and was a precursor to the subsequent, larger regionwide programs. During its two and a half years of operation, the Pilot Program provided free home energy audits to 7,200 electrically-heated households and zero-interest weatherization loans to 4,100 of these homes (Hirst et al. 1983a; Bonneville 1984a).

An Interim Program was offered to the region's private and public utilities in November 1981 and ran until September 1983. By the time the Interim Program was completed, 96 of 135 eligible utilities had signed up (Eissler 1984), and the Program had retrofitted 104,000 homes at a total cost to Bonneville of $\$ 157$ million.

The Interim Program encouraged the installation of retrofit measures by offering cash rebates that averaged $\$ 1,330$ (or $85 \%$ of the total costs) for installation of recommended retrofit measures. Two sets of retrofit measures were included in the Interim Program. All eligible houses could have the following set of measures installed: ceiling insulation and appropriate ventilation, unfinished exterior wall insulation, cold- and hot-water pipe insulation, dehumidifiers, clock thermostats, and heating-äuct insulation. Only houses meeting the Interim Program's indoor air-quality criteria qualified for installation of "house-tightening" 


$$
3 / 4
$$

measures: storm windows, storm doors, caulking, weatherstripping, and outlet and switchplate gaskets. Although all housing types (other than mobile homes) built before 1981 with electric space-heat were eligible, the vast majority of the Interim Program's participants lived in single-family homes and were homeowners.

The Interim Program demonstrated that residential weatherization was a significant, steady, and reliable energy resource that could be purchased by Bonneville. As a result, Bonneville designed a long-term weatherization program that was to operate through 1990.

Bonneville offered the Long-Term RWP to its contracting utilities in July 1983. Budget targets were designed to achieve an annuai participation rate of 3-5\% of homes within participating utilities' service territories. Incentives to non-low-income consumers were set at $\$ 0.292$ per $\mathrm{kWh}$ of estimated first-year energy savings.

Since 1983 the program has experienced a variety of budgetary and programmatic changes. Program expenditures were $\$ 142$ million in FY 1983, but have since been reduced to $\$ 40$ million in FY 1984, \$41 million in FY 1985, and \$36 million in FY 1986 for non-lowincome households. At the beginning of FY 1985, the non-low-income consumer incentive was increased nearly 3 cents to $\$ 0.32$ per $\mathrm{kWh}$ of estimated first-year energy savings, and "house-tightening" measures were made available to all program participants, not just those meeting indoor air-quality standards. 


\section{RESEARCH METHODS}

\subsection{SAMPLING}

The sample of participants for this study was selected by Bonneville from its Data Gathering Project (DGP) database. The DGP was developed and implemented in 1985 to facilitate evaluation of Long-Term RWP impacts. The DGP is composed of twelve utilities distributed across the region'; three climate zones and four states, and is intended to be representative of the entire RWP. Participating utilitics are required to complete and submit to Bonneville worksheet forms that contain data on the types and numbers of recommended and installed measures; the actual costs of the installed measures to the consumer, utility, and Bonneville; and the corresponding audit-estimated savings per instalied measure. If less than 20 residential customers have retrofit work done in any one month, the utility is required to submit worksheets on each customer. In the event that more than 20 customers participate in any one month, a random sample of 20 of those parlicipants is drawn and worksheets are submittec for those selected. Each utility applies the same random silmpling plan (developed by Bonneville) in order to identify a control or nonparticipating group.

The present analysis does not include five: utilities in the DGP. Benton County PUD operated a residential-weatherization program in 1986 that was substantially different from the Bonneville Long-Term RWP and was therefore excluded from the study. Three other utilities (Douglas Electric Co-op, Oregon; Lincoln Electric Co-op, Montana; and Kootenai Electric Co-op, Washington) were also excluded because they participated in Bonn sville's Wood Heat Displacement Program (WHDP) during 1987 and 1988. Under the WHDP, Bonneville sold incremental energy to participating utilities at reduced wholesale rates in order to encourage households to use less wood and more electricity' for space heating. Significant numbers of residential customers (9\% at Douglas, $10 \%$ at Lincoln, and $12 \%$ at Kootenai) participated in the WHDP and benefitted from the lower ciectricity rates. It is not known which of the paiticipants and nonparticipants in the Long-Term RWP also participated in the WHDP. These three utilities were removed from the present analysis becalise the two program effects could not be isolater. ${ }^{1}$ Additionally, Missoula Electric Co-op was

\footnotetext{
'Idaho Falls was also included in the WHDP. However, only $1 \%$ of Idaho Falls' customers participated. It is felt that this low participation rate in the WHDP does not confound program effects in the Long-Term RWP.
} 
removed since data attrition had reduced the number of participating households that could be analyzed to zero.

\subsection{DATA COLLECTION ANI SCREENING}

Utility billing records for the third postretrofit year (1988-89) were obtained from the utiuties by ERCE which requested the appropriate records from each utility for the period July 1988 through June 1989 for participants and nonparticipants. Average daily temperature data for the same period as the billing records we obtained from the National Oceanic and Atmospheric Administration (NOAA) for veather stations that correspond to the utilities.

Since the present stuciy was designed to focus on single-family, non-low-income residential electricity customers, households not meeting these sriteria were removed from the study sample. Furthermore, customers that had participated in other progratus or at other times in the RWP were excluded from the siudy sample. Finally, households were excluded that had received weat herization treatment under the 1986 Long-Term RWP either carly (before April 1) or late (afier September 30) in 1986. We felt that prior program participation or retrofit activity outside of a selected time frame would distort the energy savings that could be attributed to the 1986 Long-Term RWP. Previous research has indicated that no bias is introduced when removing winter retrofits from the analysis (Brandis and Bronfman 1987), because costs and implementation rates are similar between summer and winter of the same program year. After removing these households, the resulting sample size for each utility is shown in Column 4 of Table 2.1.

The utility billing records were further screened to identify households that had moved during the original study period. For participants, approximately $13 \%$ of the households listed in Column 4, Table 2.1, either relocated after weatherization or their billing records contained anomalous data that could not be resolved. For instance, a scan of the billing records revealed houses with monthly $\mathrm{kWh}$ values as high as 95,000 and as low as $-90,000$; these records were removed from analysis. The households that survived this cut for the original analysis are shown in Column 5.

Weather-normalization using the Princeton Scorekeeping Method (PRISM, described below) was then applied to the billing records of both participant and control households in order to obtain an estimate of electric-energy use under normal weather conditions. Subsequently, another $25 \%$ of participant and nonparticipant households were removed from 
Table 2.1. Data attrition and sample sizes

\begin{tabular}{|c|c|c|c|c|c|c|c|c|}
\hline \multirow{3}{*}{ Utility } & \multirow{3}{*}{$\begin{array}{c}\text { Worksheets }{ }^{\mathrm{a}} \\
\text { (1) }\end{array}$} & \multicolumn{4}{|c|}{ Participants } & \multirow{2}{*}{\multicolumn{3}{|c|}{ NACs/Worksheets ${ }^{e}$}} \\
\hline & & \multicolumn{2}{|c|}{ Exclusions $^{\mathrm{b}}$} & \multirow{2}{*}{$\begin{array}{l}\text { Studyc } \\
\text { (4) }\end{array}$} & \multirow{2}{*}{$\begin{array}{l}\text { Bills }^{d} \\
(5)\end{array}$} & & & \\
\hline & & (2) & (3) & & & $(6)$ & (7) & $(8)$ \\
\hline Tacoma & 249 & 67 & 99 & 83 & 72 & 59 & 50 & 44 \\
\hline Snohomish & 243 & 96 & 86 & 61 & 57 & 38 & 36 & 31 \\
\hline Elmhurst & 123 & 28 & 36 & 59 & 57 & 45 & 45 & 40 \\
\hline Richland & 240 & 60 & 105 & 75 & 51 & 42 & 42 & 31 \\
\hline Eugene & 240 & 58 & 99 & 83 & 62 & 49 & 46 & 41 \\
\hline Vera & 170 & 55 & 54 & 61 & 69 & 44 & 39 & 30 \\
\hline Missoula ${ }^{\mathrm{f}}$ & 46 & 8 & 22 & 16 & 14 & 10 & 0 & 0 \\
\hline Idaho Falls & 191 & 21 & 95 & 75 & 63 & 58 & 57 & 35 \\
\hline Sub-Tctals & 1502 & 393 & 596 & 513 & 445 & 345 & 315 & 252 \\
\hline \multirow{3}{*}{ Utility } & \multirow{3}{*}{\multicolumn{4}{|c|}{ Nonparticipants }} & & \multirow{2}{*}{\multicolumn{3}{|c|}{$\mathrm{NACs}{ }^{\mathrm{e}}$}} \\
\hline & & & & & Bills $^{d}$ & & & \\
\hline & & & & & $(9)$ & $(10)$ & (11) & (12) \\
\hline Tacoma & & & & & 283 & 235 & 224 & 201 \\
\hline Snohomish & & & & & 166 & 101 & 82 & 58 \\
\hline Elmhurst & & & & & 68 & 45 & 42 & 36 \\
\hline Richland & & & & & 151 & 116 & 107 & 96 \\
\hline Eugene & & & & & 266 & 189 & 158 & 149 \\
\hline Vera & & & & & 151 & 105 & 63 & 52 \\
\hline Missoula ${ }^{f}$ & & & & & 80 & 71 & 52 & . \\
\hline Idaho Falls & & & & & 174 & 133 & 127 & 96 \\
\hline Sub-Totals & & & & & 1339 & 995 & 855 & 688 \\
\hline
\end{tabular}

aTotal number of DGP worksheets maintained by Bonneville and provided by the respective utilities under the random sample plan.

"Houses in column 2 include low-income households, multifamily structures, houses that had participated in the 1985 Long-Term RWP, and houses that had two separate installations of retrofit measures as part of the 1986 Long-Term RWP. Houses in column 3 were retrofit either before 4/1/86 or after $9 / 3(3) / 86$.

The study sample: (1) - [(2) + (3)].

${ }^{\mathrm{d} B i l l s}$ collected by ERCE from the utilitics for the houses in columns 5 and 9.

${ }^{e}$ Houses in column 6 have workshects and NACs for the preretrofit year $(85 / 86)$ and the first postretrofit year (86/87). Houses in column 7 have worksheets and NACs for 85/86, 86/87, and $87 / 88$. Houses in column 8 have workshects and NACs for $85 / 86,86 / 87,87 / 88$, and $88 / 89$. Nonparticipants do not have worksheets.

Not retained in analysis of houscholds with three postretrofit years of billing histories. 
the analysis of first postretrofit year savings, due to insufficient or incomplete billing records and negative space heating or baseload estimates from PRISM (indicating a preponderance of multiple-fuels use), or poor-fitting PRISM models (i.e., R-squares of less than 0.25).

Specifically, the screening criteria that were developed for the original analysis and applied to the PRISM musuels consisted of five steps. First, we required that at least two years of billing history (the preretrofit year of $1985 / 86$ and the first postretrofit year of 1986/87) were available for each house to be analyzed. Second, we removed from analysis any house that used less than $3,000 \mathrm{kWh}$ in any one year for whole-house electricity needs including lighting, water heating, and space heating. This second criterion is expected to identify supplemental or multiple fuel users (woodusers, among others) and energy users whose energy-use patterns are not representative of Bonneville's residential customers. Third, houses whose PRISM estimates of electric space heating were zero or less were not retained in the analysis. These houses probably supplement their electric space-heating needs with other fuels, or the energy-use patterns in these houses are more erratic than the present analysis and available data can control. Fourth, we required that each year of billing history span at least 240 consecutive days, two-thirds of a complete year of history. This criterion is expected to identify houses with problems in their electricity accounts, vacations or other periods when the house is not occupied, and changes in occupancy that may have otherwise been overlooked. Finally, we removed houses whose model R-squares from PRISM were less than 0.25 , thus excluding from the analysis houses whose energy-use patterns are not typical of all-eleciri: residential energy users. The re'naining households are shown in Columns 6 and 10 (Table 2.1). The total number of participant households for which savings one year after weatherization could be calculated was 345; for nonparticipants, the number was 995 .

The total number of participant households for which savings two years after weatherization could be calculated was 315 (Column 7); for nonparticipants, the number was 855 (Column 11).

The screening criteria were similarly applied to the updated billing histories. The number of houses listed in Columns 8 and 12 of Table 2.1 are those for which sufficient data were available to identify savings three years after weatherization. There were 252 participants and 688 nonparticipants with the necessary data. 


\subsection{DATA ANALYSIS}

Electricity bills were weather-adjusted using PRISM (see Fels 1986, for a detailed discussion). The basic assumption of PRISM is that residential energy consumption and outdoor temperature are linearly related. PRISM uses average daily energy consumption and average daily outdoor temperature to fit the following linear model for each housing unit:

$$
F_{i}=a+b H_{i}(t)+e_{i} \text {. }
$$

where,

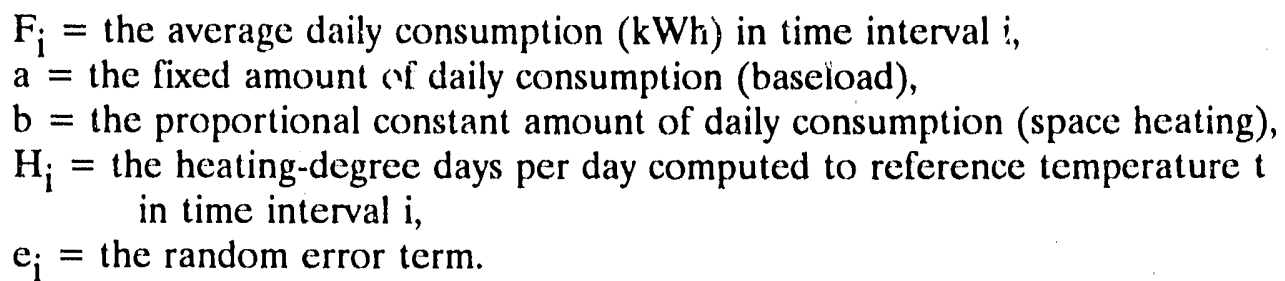

Normalized Annual Consumption (NAC) is then calculated as follows:

$$
\mathrm{NAC}=365 \mathrm{a}+\mathrm{bH}_{\mathrm{o}}(\mathrm{t})
$$

where,

$365 \mathrm{a}=$ the fixed amount of base load electricity consumed by a household in one year,

$\mathrm{H}_{\mathrm{O}}(\mathrm{t})=$ the heating-degree days (base $\mathrm{t}$ ) in a typical year, so that

$\mathrm{bH}_{\mathrm{O}}(\mathrm{t})=$ the proportional amount of heating fuel relative to the outdoor temperature, adjusted for long-term outdoor temperatures.

NACs were calculated for each participant and control household for each of the four household-years that data were available: July 1985 through June 1986, the preretrofit year; July 1986 through June 1987, the first postretrofit year; July 1987 through June 1988, the second postretrofit year; and July 1988 through June 1989, the third postretrofit year. Gross energy savings (DNAC or change in NAC) were estimated for each household by subtracting NAC of the first, second, or third postretrofit year from NAC of the preretrofit year, where

$$
\mathrm{DNAC}=\mathrm{NAC}_{0}-\mathrm{NAC}_{1} \text { or } 2 \text { or } 3 .
$$

Thus, a positive value for DNAC indicates a reduction in energy use (i.e., an energy savings).

Net energy savings - the portion of the savings that can be attributed to the program - were estimated at the utility and program levels. Average DNACs were calculated for each utility for participant and control groups. The control group average DNACs were then 
subtracted from the average DNACs for participants. The difference is the average net energy savings per household for the specific utility.

Nearly all of the 27 retrofit measures that could be installed under the 1986 LongTerm RWP were developed to save weather-sensitive or space-heating electricity use, although hot-water pipe wrap and domestic hot - water heater (DHWH) insulation were also eligible retrofit measures. Space-heating electricity use and savings (gross and net) were therefore estimated using PRISM parameters. The estimate for heating, however, is not as robust as NAC itself (Fels, Rachlin, and Socolow 1986). It has been shown that hidden, nonheating factors such as the weather-sensitive portion of water heating and lighting cause PRISM to overestimate space heating (Fels et al. 1986).

A validation of PRISM, sponsored by Bonneville, was conducted at Oak Ridge National Laboratory using submetered data on single liamily electricity use collected as part of the Hood River Conservation Project. In that study, Hwang (1989) estimates that the heating component of NAC as estimated by PRISM could be overestimated by as much as 19\%. Hirst and Goeltz (1986) found that PRISM overestimated space heating by $29 \%$ in houses that used multiple fuels for heating and by $6 \%$ in houses that used a single fuel. Given the data available for this study, it was not possible to explore further the accuracy of PRISM's estimation of the space-heating component.

\subsection{UTILITY WEIGHTS}

For a variety of reasons, rates of participation in conservation programs typically vary across utilities. Among the seven utilities studied here, participation rates in the 1986 LongTerm RWP ranged from $2.7 \%$ for the Tacoma Public Utilities to $7.1 \%$ for the Eugene Water and Electric Board (Table 2.2).

Furthermore, utilities vary widely in the number of customers they serve. In this update of seven utilities, nearly half of the approximately 230,000 households that were eligible to participate in the 1986 Long-Term RWP were served by one utility, the Snohomish

Public Utility District. At the other extreme, Vera served less than $2 \%$ of the eligible households.

Weights were developed for each utility's participant and control groups to reflect the relative contribution of each to energy savings by all 1986 participants and nonparticipants, respectively, from the seven utilities in this update. (Please note that program statistics are 


\section{1/12}

Table 2.2. Utility weights and participation rates for 1986 Long-Term RWP

\begin{tabular}{|c|c|c|c|c|c|}
\hline \multirow[b]{2}{*}{ Utility } & \multicolumn{2}{|c|}{ Participants } & \multicolumn{2}{|c|}{ Nonparticipants } & \multirow{2}{*}{$\begin{array}{c}\text { Participation } \\
\text { Rate } \\
(\%)\end{array}$} \\
\hline & $\begin{array}{c}\text { Houses } \\
\text { Weatherized }^{a}\end{array}$ & $\begin{array}{l}\text { Utility } \\
\text { Weighı. }\end{array}$ & $\begin{array}{c}\text { Eligible } \\
\text { Households }\end{array}$ & $\begin{array}{l}\text { Utility } \\
\text { Weight }\end{array}$ & \\
\hline Snohomish Public Utility Distric & rict 3,517 & .3728 & 101,861 & .4654 & 3.3 \\
\hline Eugene Water \& Electric Board & rd 3,127 & .3315 & 40,899 & .1869 & 7.1 \\
\hline Tacoma Public Utilities & 1,425 & .1511 & 51,304 & .2344 & 2.7 \\
\hline Richland, City of & 643 & .0682 & 10,426 & .0476 & 5.8 \\
\hline Idaho Falls, City of & 343 & .0364 & 6,584 & .0300 & 5.0 \\
\hline Vera Irrigation District & 234 & .0248 & 3,452 & .0158 & 6.4 \\
\hline Elmhurst Mutual Power \& Ligh & 144 & .0153 & 4,330 & 0198 & 3.2 \\
\hline Missoula Electric Co-op ${ }^{b}$ & 46 & - & 1,722 & - & 2.6 \\
\hline Tolals & 9,433 & 1.00000 & 218,856 & $1.0000)$ & 4.1 \\
\hline
\end{tabular}

aTotal calendar year 1986 weatherizations in Long-Term RWP. Based upon data obtained from the Bonneville Office of Conservation 1986 Yearbook.

"Not retained in analysis of electricity savings three years after weatherization. Missoula is included in this table because it was included in the original study.

reported for Missoula in Table 2.2 but that the utility weights and column totals do not include Missoula program statistics.) For participants, the weighting factor was calculated for each utility based upon the number of houses retrofit by the utility during calendar year 1986 relative to the total number of houses weatherized by all seven utilities retained for this update (see Table 2.2). For the control group, the weighting factor is the utility's share of eligible non articipants relative to the total number of all nonparticipants in the seven utilitics. 


\section{MEASURES RECOMMENDED AND INSTALLED}

This chapter reviews the retrofit measures that were recommended and installed by Bonneville's 1986 Long-Term RWP. It should be noted that the results of audit and retrofit analysis in the original study were not different from a similar analysis conducted with the updated sample. In other words, data attrition associated with collecting a fourth year of billing histories did not introduce a bias. (See Appendix A.)

Where possible, the 1986 RWP findings are presented alongside those findings reported in prior evaluations of Bonneville's weatherization efforts. When comparisons are being made with the findings from previous evaluation research, dollars are inllated to 986 values using 1981 through 1986 Consumer Price Ind rxes for the Seattle-Everett, Washington area. Measures are also aggregated into the broad categories used in earlicr evaluations to facilitate comparison.

The retrofit measures that were recommended and installed in homes of participating houscholds are examined here primarily as a means of understanding installation rates, predicted savings, and costs. As a result, we focus on those 345 participants of the 1986 Long-Term RWP with a minimum of one year of postretrofit billing data in order to maintain the largest possible sample.

A total of 1,945 measures were recommended for instaliation in these 345 homes, representing 27 different types of measures. More than four-fifths $(83 \%)$ or 1,611 of these recommended measures were installed. In 1982 and 1983, 70\% of the recommended measures were installed by the Bonneville program (Hirst, et al., 1985) and in 1985 the measure installation rate was $78 \%$ (Horowitz, et al., 1987). Thus, there appears to be a slighi increase over time in the percentage of recommended measures that were actually installed. This increase in the rate of installing measures recommended by the program can be attributed to improved program delivery and to greater interest in residential conservation demonstrated by utility customers and utilities in the Bonneville service area.

There was considerable variation in installation rates acrosi, ietrofit measures (Table 3.1). At the low end, four types of measures were never installed: cold-water pipe insulation, interior- and exterior-surface roof insulation, and dehumidifiers. Another six types of measures were installed in no more than $1 \%$ of the homes: interior- and exterior-crawlspace 
Table 3.1. Measures installed

\begin{tabular}{|c|c|c|c|c|c|}
\hline Measure ${ }^{a}$ & $\begin{array}{l}\text { Percent } \\
\text { commended }\end{array}$ & $\begin{array}{l}\text { Percent } \\
\text { installed }\end{array}$ & $\begin{array}{l}\text { Cost per } \\
\text { installation } \\
\text { (in 1986-\$) }\end{array}$ & $\begin{array}{c}\text { Audit- } \\
\text { estimated } \\
\text { savings } \\
\text { (kWh/year) }\end{array}$ & $\begin{array}{c}\text { Cost per kWh } \\
\text { of estimated } \\
\text { savings } \\
\text { (in 1986-\$) }\end{array}$ \\
\hline Ceiling insulation (attic) & 85.0 & 76.8 & 636 & 1,727 & .37 \\
\hline Weatherstripping & 71.1 & 44.4 & 58 & 44 & 1.32 \\
\hline Caulking & 68.6 & 38.0 & 74 & 127 & 0.58 \\
\hline Floor insulation (over crawl space & се) 67.7 & 60.5 & 788 & 2,243 & 0.35 \\
\hline Multiglazed windows & 56.2 & 47.5 & 1,326 & 1,514 & 0.88 \\
\hline Storm windows & 37.1 & 31.9 & 885 & 1,466 & 0.60 \\
\hline Duct insulation & 29.9 & 27.3 & 272 & 1,408 & 0.19 \\
\hline Sliding glass doors & 28.9 & 27.6 & 415 & 578 & 0.72 \\
\hline Clock thermostat & 26.3 & 13.6 & 150 & 263 & 0.57 \\
\hline Wall insulation (exterior aavity) & 26.2 & 22.6 & 478 & 2,207 & 0.22 \\
\hline Wall insulation (unfinished) & 14.0 & 13.4 & 250 & 1,639 & 0.15 \\
\hline Crawlspace (exterior) & 12.6 & 0.8 & 530 & 998 & 0.53 \\
\hline Windows (sash mounted) & 11.5 & 7.4 & 204 & 185 & 1.10 \\
\hline Basement wall insulation (interior & or) 7.2 & 3.8 & 429 & 1,858 & 0.23 \\
\hline Floor insulation (basement) & 4.8 & 4.8 & 263 & 853 & 0.31 \\
\hline Windows (vent conversion) & 4.6 & 4.0 & 1,151 & 1,555 & 0.74 \\
\hline Water heater wrap & 2.8 & 2.6 & 36 & $\mathrm{n} / \mathrm{a}$ & $\mathrm{n} / \mathrm{a}$ \\
\hline Floor insulation (exposed) & 2.7 & 0.7 & 748 & 63 & 11.87 \\
\hline Doors (French and sliding) & 1.5 & 0.7 & 571 & 304 & 1.88 \\
\hline Crawlspace (interior) & 1.0 & 0.1 & 563 & 1,073 & 0.52 \\
\hline Water heater pipe insulation & 0.6 & 0.6 & 117 & $\mathrm{n} / \mathrm{a}$ & $n / a$ \\
\hline Wall insulation (exterior surface) & 0.1 & 0.1 & 88 & 1,133 & 0.07 \\
\hline
\end{tabular}

${ }^{a}$ No interior- or exterior-surface roof insulation, cold-water pipe wrap, air-to-air heat exchangers, or denumidifiers were installed.

Note: Based upon 1,945 installations of 27 measures in 345 homes.

insulation, exposed floor insulation, exterior-surface wall insulation, water-heater pipe insulation, sliding glass doors, and French doors.

At the other extreme, ceiling insulation was recommended to $85 \%$ of the 1986 LongTerm RWP participants and was installed in $77 \%$ of the homes, representing the measure that was installed most often. The next four most recom:nended and installed measures were weatherstripping, caulking, floor insulation (over the crawlspace), and multiglazed windows.

Some measures were installed in almost all of the homes which need them, based on audit results. Ceiling, floor, wall, and duct insulation are examples. Other measures were installed in a much smaller proportion of the recommended homes. Weatherstripping and caulking were the two measures with the greatest disparity between rates of recommendation 
and installation. In both cases, the measure was installed in only about $60 \%$ of the recommended homes. While these two infiltration measures are inexpensive, their estimated energy savings are also modest, resulting in a high ratio of costs to savings. This low level of cost effectiveness may account for their low penetration levels. These measures were also easily installed by the homeowner, and thus may have been installed by program participants without assistance from the RWP. In any event, the same pattern of relatively low installation rates for these two measures was identified in the 1982, 1983, and 1985 RWP evaluations (Hirst, et al. 1985; Horowitz, et al. 1987).

Installation rates and predicted savings for recommended and installed measures are shown in Table 3.2, by utility. Mean values are also presented for the program as a whole, both unweighted and weighted; the latter best represents the regionwide program. The average number of recommendations per house for the program as a whole was 5.6 and the average number of measures installed was 4.7 .

Table 3.2. Audit-estimated savings

\begin{tabular}{|c|c|c|c|c|}
\hline $\begin{array}{c}\text { Utility } \\
\text { (No. of RWP } \\
\text { houscholds) }\end{array}$ & $\begin{array}{l}\text { Number of } \\
\text { Measures } \\
\text { Installed }\end{array}$ & $\begin{array}{c}\text { Audit- } \\
\text { Estimated } \\
\text { Savings } \\
\text { from Installed } \\
\text { Measures } \\
\text { in } \mathrm{kWh} / \mathrm{yr}(\mathrm{A})\end{array}$ & $\begin{array}{c}\text { Audit- } \\
\text { Estimated } \\
\text { Savings from } \\
\text { Recommended } \\
\text { Measures } \\
\text { in } \mathrm{kWh} / \mathrm{yr} \text { (B) }\end{array}$ & $\begin{array}{l}\text { Percent of } \\
\text { Potential } \\
\text { Audit- } \\
\text { Estimated } \\
\text { Savings }\end{array}$ \\
\hline Tacoma $(\mathrm{N}=59)$ & 4.6 & 4,589 & 4,999 & 91.8 \\
\hline Idaho Falls $(N=58)$ & 6.8 & $7,6(0) 7$ & 7,907 & 96.2 \\
\hline Eugene $(N=49)$ & 5.5 & 5,438 & 6,096 & 89.2 \\
\hline Elmhurst $(\mathrm{N}=45)$ & 5.4 & 5,531 & 5,884 & 94.0 \\
\hline $\operatorname{Vera}(N=44)$ & 2.8 & 4,439 & 4,910 & 90.4 \\
\hline Richland $(N=42)$ & 3.0 & 3,498 & 3,940 & 91.1 \\
\hline Snohomish $(N=38)$ & 4.1 & 6,112 & 7,268 & 84.1 \\
\hline Missoula $(\mathrm{N}=10)^{\mathrm{b}}$ & 2.8 & 2,954 & 3,139 & 94.1 \\
\hline \multirow[t]{2}{*}{ Program Summary ${ }^{c}$} & 4.7 & 5,308 & 5,807 & 91.4 \\
\hline & 4.7 & 5,435 & 6,127 & 88.7 \\
\hline
\end{tabular}

${ }^{a}$ Defined as $(\mathrm{A} / \mathrm{B})^{*} 10()$.

"Not retained in analysis of electricity savings three years after weatherization. utility.

"The numbers in the bottom of the t'we rows in Program Summary are weighted by

Source: 345 participant homes weatherized in 1986. 
Overall, the average audit-estimated energy savings per house for all reeo amended measures were $6,127 \mathrm{kWh} /$ year, and estimated savings for installed measures were 5,435 $\mathrm{kWh} / y e a r$. One way of summarizing this information is to compute the percent of potential audit-estimated savings that are actually captured by dividing the audit-estimated savings frem installed measures by the audit-estimated savings from recommended measures, and multiplying by 100 . The result $(89 \%)$ indicates that households are more likely to install measures that are estimated to be more energy-conserving, since overall only $83 \%$ of the recommended measures were installed.

Table 3.3 presents the average weatherization costs for the program as a whole based on the sarnple of 345 participants, and for each of the utilities. For the entire sample, the average, regionally-weighted job cost (c.cluding administrative costs) was $\$ 2,388$ (in 1986-\$). The 1986 costs increased to $\$ 2,788$ when the $\$ 400$ average administrative costs were included. This exceeds the cost of the average job in each of the three previous evaluation years: 1982 , 1983, and 1985. Of the total job cost in $1986,63 \%$ was reimbursed by Bonneville and the customer contribution averaged $\$ 743$ or $31 \%$. In previous years the customer contribution was less: it was $26 \%$ of the total cost of the job in $1985,20 \%$ in 1983 , and only $6 \%$ in 1982 .

Table 3.3. Weatherization costs

\begin{tabular}{lcccc}
\hline & $\begin{array}{c}\text { Total Retrofit } \\
\text { Cost } \\
\text { (in 1986-\$) }\end{array}$ & \multicolumn{3}{c}{$\begin{array}{c}\text { Distribution of Costs } \\
\text { (in percents) }\end{array}$} \\
\cline { 5 - 6 } & Customer & Utility & Bonneville \\
\hline Tacoma & 2,384 & 41.8 & 8.7 & 49.5 \\
Idaho Falls & 2,484 & 19.2 & 0 & 80.6 \\
Eugene & 2,398 & 27.7 & 6.4 & 65.9 \\
Elmhurst & 2,599 & 33.8 & 0 & 66.2 \\
Vera & 997 & 18.3 & 0 & 81.7 \\
Richland & 1,913 & 40.3 & 0 & 59.7 \\
Snohomish & 2,560 & 28.5 & 7.0 & 64.5 \\
Missoulab & 1,160 & 27.5 & 0 & 72.5 \\
\hline Program Summary & 2,181 & 29.9 & 3.2 & 66.9 \\
& 2,388 & 30.9 & 6.1 & 63.0 \\
\hline
\end{tabular}

${ }^{a}$ Excludes administrative costs which average $\$ 400$.

${ }^{b}$ Not retained in analysis of electricity savings three years after weatherization. 'The numbers in the bottom of the two rows in Program Summary are weighted by utility. Source: 345 participant homes weatherized in 1986. 


\section{$17 / 18$}

Total retrofit costs vary greatly across the utilities, as does the distribution of costs across the three contributors: Bonneville, the utility, and the customer. For Vera and Missoula, for instarice, the total retrofit costs were $\$ 997$ and $\$ 1,160$, respectively for the average consumer. For Snohomish and Elmhurst, on the other hand, the total costs typically exceeded $\$ 2,500$. Only three of the utilities (in the original 1986 Long-Term RWP study) contributed to the expense of installing measures (Tacoma, Snohomish, and Eugene), and their reimbursements were less than $10 \%$ in each case.

It is interesting to note that there is little correspondence between the average customer contribution in a utility and that utility's rate of participation in the 1986 Long-Term RWP. For example, among the four utilities with the highest participation levels, the levels of customer contribution as a percent of the total job cost range from $18 \%$ to $40 \%$. Thus, high levels of customer cost-sharing do not appear to deter participation. 


\section{ENERGY SAVINGS}

Based on billing histories provided by the seven utilities described in Chapter 2 , annual energy use and savings were calculated for all sample households. There were 252 participant households for which at least four complete years of data were available, allowing the valculation of energy use for one year prior to weatherization ard three years alterwards. Four years of complete data also were available for 688 nonparticipants. Changes of occupancy and anomalous data caused the sample to shrink from the 345 participant and 995 nonparticipant houscholds for which only two complete years of data were analyzed in the original evaluation.

Once houschold energy use and savings were calculated for the sample of participants and nonparticipants described above, these data were then aggregated and examined at the utility level. Finally, utility savings were weighted, using the weights shown in Table 2.2 , to allow the identification of overall program savings. Each of these different levels of analysis will be discussed in the following sections, beginning with energy use and savings by individual houscholds.

\subsection{HOUSEHOLD SAVINGS}

We began by comparing the average weather-adjusted annual electricity consumption of RWP participants and nonparticipants, for the year prior to their weatherization. We found that those households in this update that participated in the program in 1986 used more electricity prior to weatherization than did the nonparticipants. Table 4.1 shows that the sample of 1986 participants $(\mathrm{N}=252)$ used nearly 2,040 (weighted) kWh more than the sample of nonparticipants $(\mathrm{N}=688)$, and that the two groups are different at the 0.01 significance level. This finding is consistent with the results of previous studies of residential conservation programs in the Pacific Northwest and elsewhere (Hirst et al. 1983b; Goldberg 1986; Brown and White 1988). Participants generally consume more energy prior to weatherization than houscholds that choose not to participate in weatherization programs.

However, this characteristic difference in preprogram electricity eonsumption between participant and control group houscholds has become less distinct over time. In the Pilot Program administered during 1980) through 1982, participating houscholds included in the evaluation used $30,280 \mathrm{kWh} /$ year in the preweatherization year while nonparticipants used 
Table 4.1. Comparison of weighted preretrofit normalized annual consumption for program participants and nonparticipants

\begin{tabular}{lcccc}
\hline & $\begin{array}{c}\text { P'articipants' } \\
\text { mean pre- } \\
\text { retrofit NAC }\end{array}$ & $\begin{array}{c}\text { Nonparticipants' } \\
\text { mean } \\
\text { preretrofit NAC }\end{array}$ & $\begin{array}{c}\text { Participants' } \\
\text { preretrofit } \\
\text { NAC minus } \\
\text { nonparticipants' } \\
\text { preretrofit NAC }\end{array}$ & $\begin{array}{c}\text { Significance of } \\
\text { difference between } \\
\text { participants' and } \\
\text { nonparticipants' } \\
\text { prerctrofit NAC }\end{array}$ \\
\hline $\begin{array}{l}\text { Normalized annual } \\
\text { consumption (NAC) }\end{array}$ & $24,310 \mathrm{kWh}$ & $22,270 \mathrm{kWh}$ & $2,040 \mathrm{kWh}$ & $\mathrm{p}=.01$ \\
Reference temp. $\left({ }^{\circ} \mathrm{F}\right)$ & 59 & 61 & $\ldots$ & $\ldots$ \\
Model $\mathrm{R}^{2}$ & 0.90 & 0.90 & $\ldots$ & $\ldots$ \\
$\begin{array}{l}\text { Number of households } \\
\text { in sample }\end{array}$ & 252 & 688 & $\ldots$ & $\ldots$ \\
\hline
\end{tabular}

${ }^{1}$ Participants and nonparticipants shown here are all those households for which at least four complete years of billing data were obtained.

$25,780 \mathrm{kWh}$ /year. Thus, participants used nearly $18 \%$ more electricity than nonparticipants. In the 1986 Long-Term RWP, participants used $24,310 \mathrm{kWh}$ (weighted) in the preretrofit year while the control group households used an average of $22,270 \mathrm{kWh}$ (weighted). Participants used only $9 \%$ more electricity than nonparticipants. From the Pilot Program to the 1986 Long-Term RWP, the difference in preprogram electricity consumption between participants and control group households declined by almost $50 \%$. In other words, program participants and control group households have become more similar in terms of preprogram electricity consumption.

Gross electricity savings achieved by participating households one, two, and three years after weatherization are shown in Figure 4.1. Gross savings are calculated by subtracting postretrofit NAC from preretrofit NAC. If the amount of energy consumed after a home is weatherized is less than was used before, gross savings are positive; if energy use goes up following weatherization, gross savings are negative. Based upon the updated sample, participants' gross savings for the first year following weatherization have a mean of 1,928 $\mathrm{kWh}$ and a standard deviation of $4,116 \mathrm{kWh}$. These numbers and the accompanying figure indicate that there was a broad range of savings and that many program participants $(29 \%)$ 


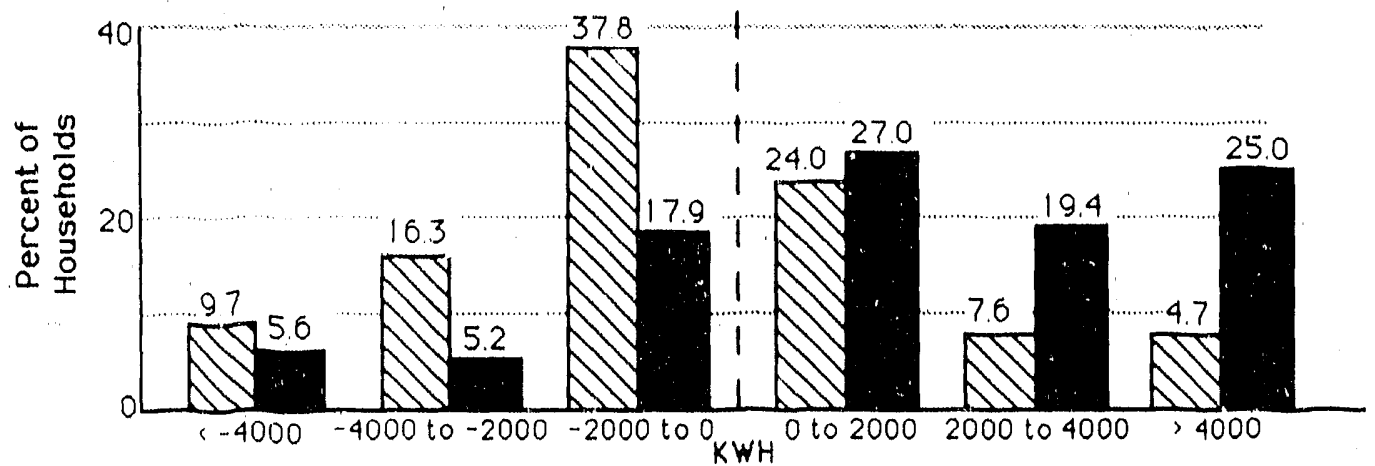

Second Year

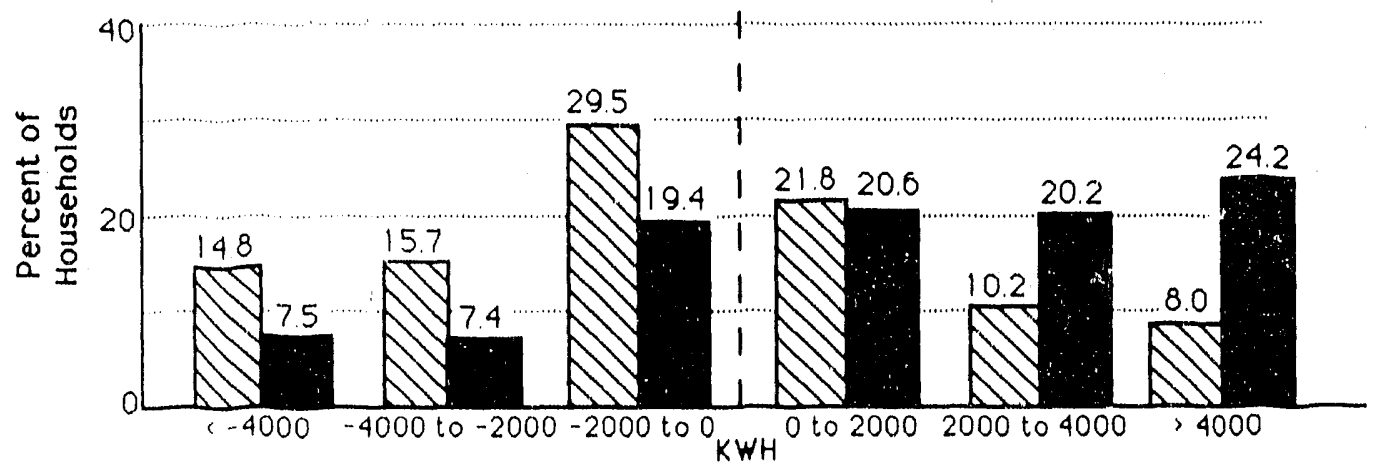

Third Year

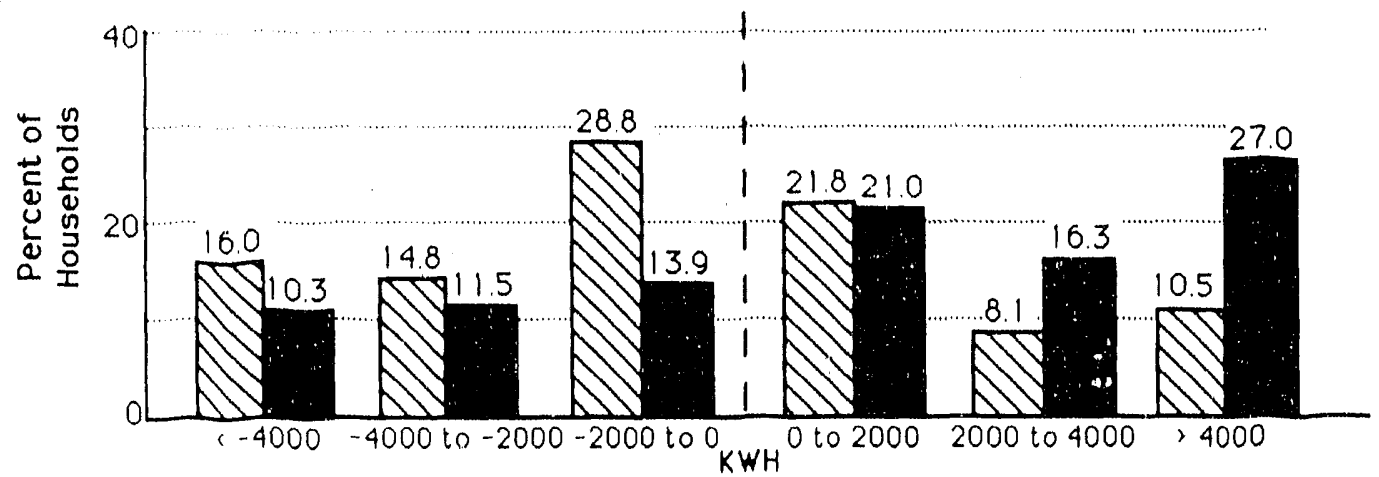

Broken vertical line represents no change in electricity use. Each vertical bar represents the percentage of households, either participants or nonparticipants as indicated, that. reduced electricity use (positive savings) or increased electricity use (negative savings), for the years shown.

Fig. 4.1. Annual gross electricity savings for program participants and nonparticipants one, two, and three years after weatherization. 
used more energy following weatherization than they did previously. This finding is common to many other studies of conservation programs, including earlier assessments of the RWP (Hirst, et al. 1983a).

As shown in Figure 4.1, nonparticipants also experienced a broad range of ent : $\mathrm{y}$ savings (i.e., changes in consumption), even in the absence of participation in the RWP. In this case, however, the mean amount saved was a negative $742 \mathrm{kWh}$, meaning that the average control household used $742 \mathrm{kWh}$ more during 1986-87 than in 1985-86. Still, the standard deviation was $3,295 \mathrm{kWh}$, indicating that many houscholds experienced substantial savings ( $36 \%$ reduced energy use), even without being weatherized through this program.

While there is a widespread distribution of energy savings for both participants and nonparticipants, there is also a distinct difference in their means: participants have clearly saved more energy than nonparticipants. A t-test of the difference between these means confirms this conclusion, at a significance level of 0.01 (see Table 4.5).

Household energy savings are difficult to predict using audit estimates, as shown by Figure 4.2. Each point on the scatter plot represents an estimate of savings made during a

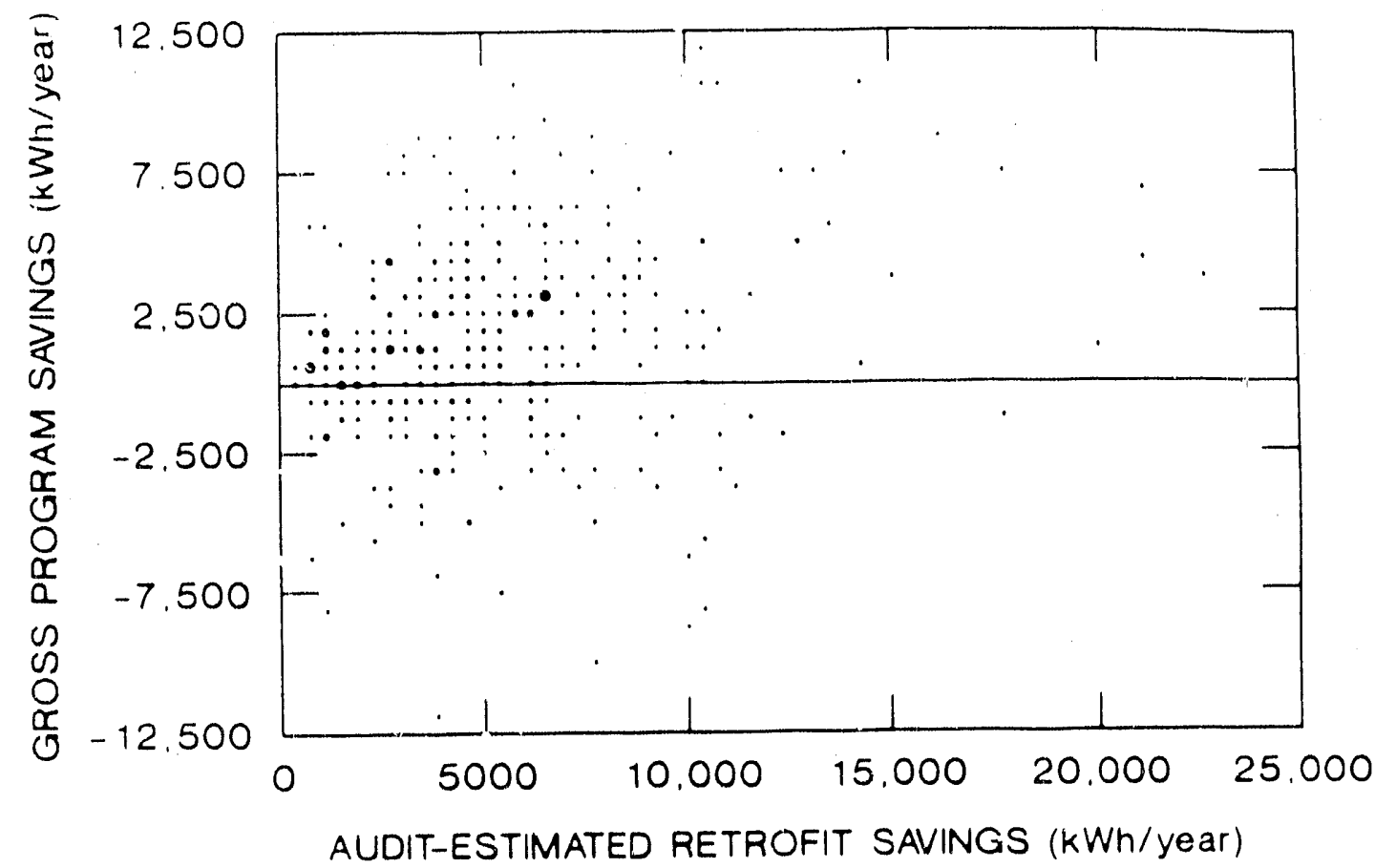

Source: Schweitzer, Brown, and White (1989), p. 29, Fig. 4.2.

Fig. 4.2. Comparison of audit-estimated savings with actual gross program electricity savings one year after weatherization. 
preretrofit energy audit and the actual energy savings achieved one year after the same home was weatherized. In general, audit-estimated savings were much higher than the savings actually realized. Again, this is frequently found in other conservation programs as well (Hirst, Goeltz, and Trumble 1989). In this study, average audit-estimated savings were approximately $5,250 \mathrm{kWh}$ for both the group with at least one complete year of postretrofit data and for the group with four complete years. Mean gross savings, however, were only $1,928 \mathrm{kWh}$ for the first year after weatherization, 1,618 for the second following year, and 1,524 for the third year after weatherization. Thus, only $29 \%$ of the estimated savings was realized during the third postretrofit year. The correlation between audit-estimated and actual savings was very low, with a correlation coefficient of 0.14 for the first postretrofit year $(\mathrm{p}=.01)$, and less than 0.10 for the third postretrofit year $(\mathrm{p}=.01)$.

In an effort to identify determinants of energy savings and to see which specific measures were most strongly associated with energy savings, a multiple regression analysis was performed using independent variables for which data were available at the household level. Due to considerations of cost and intrusiveness, some potentially important characteristics of household members and their energy consumption practices (such as family size, ages of family members, income, wood use, and actual thermostat settings) were not examined. Those variables selected include preretrofit NAC, total weatherization costs, long-run average heating degree days (HDD), and location of household (east or west of the Cascade Mountains), as well as a number of specific weatherization measures. Unfortunately, the entire set of variables used in the regression analysis explained less than $10 \%$ of the total variance in gross energy savings. For this reason, the results of that analysis will not be discussed in more detail.

\subsection{UTILITY-L.EVEL SAVINGS}

Following the household-level analysis discussed above, energy use and savings were aggregated by utility. Table 4.2 shows preretrofit NAC, NAC for the first year following weatherization (using the updated sample), and gross energy savings (the difference between these two numbers) for the first year after weatherization for each of the seven utilities in our updated sample. This table shows that, for all utilities, participants used more energy prior to weatherization than did nonparticipants. The table also shows substantial differences among utilities in average preretrofit consumption for participants and nonparticipants alike. 
Table 4.2. Average weather-adjusted electricity consumption and gross eloctricity savings one year after weatherization, by utility

\begin{tabular}{lccc}
\hline $\begin{array}{c}\text { Utility } \\
\text { (no. of households) }\end{array}$ & $\begin{array}{c}\text { Preretrofit } \\
\text { NAC }\end{array}$ & $\begin{array}{c}\text { First year } \\
\text { postretrofit } \\
\text { NAC }\end{array}$ & $\begin{array}{c}\text { First year } \\
\text { postretrofit } \\
\text { gross electricity } \\
\text { savings }\end{array}$ \\
\hline Tacoma participants (44) & 25,544 & 24,177 & 1,367 \\
Tacoma nonparticipants (201) & 24,971 & 26,212 & $-1,241$ \\
Idaho Falls participants (35) & 28,827 & 26,023 & 2,804 \\
Idaho Falls nonpariicipants (96) & 27,671 & 28,324 & -653 \\
& & & 3,312 \\
Eugene participants (41) & 21,708 & 18,396 & $-1,026$ \\
Eugene nonparticipants (149) & 18,199 & 19,225 & 1,149 \\
Elmhurst participants (40) & & & $-1,239$ \\
Elmhurst nonparticipants (36) & 27,470 & 26,321 & 750 \\
Vera participants (30) & 24,849 & 26,088 & 747 \\
Vera nonparticipants (52) & & & 2,161 \\
Richland participants (31) & 26,521 & 25,770 & -620 \\
Richland nonparticipants (96) & 25,797 & 25,050 & 1,817 \\
Snohomish participants (31) & 27,083 & 24,922 & 337 \\
Snohomish nonparticipants (58) & 25,177 & 25,797 & \\
\hline & 25,335 & 23,518 & 2,497 \\
\hline
\end{tabular}

${ }^{a}$ Electricity consumption and savings are reported in units of $\mathrm{kWh}$.

All participating utilities experienced positive gross savings in the first year and all nonparticipants but two experienced negative savings (i.e., greater energy use). Despite these basic similarities, there was substantial variation among utilities in the magnitude of savings achicved.

Table 4.3 provides preretrofit NAC plus NAC and gross savings for the second year following weatherization, by utility. Savings were calculated by subtracting second year postretrofit NAC from preretrofit NAC. During this second postretrofit year, average savings by participants were positive for all utilities, while savings by nonparticipants were negative for five utilities and positive, but small, for the other two. Once more, there was considerable variation in preretrofit NAC and in savings among utilities. 
Table 4.3. Average weather-adjusted electricity consumption and gross electricity savings two years after weatherization, by utility

\begin{tabular}{|c|c|c|c|}
\hline $\begin{array}{c}\text { Utility } \\
\text { (no. of households) }\end{array}$ & $\begin{array}{c}\text { Preretrofit } \\
N A C^{a}\end{array}$ & $\begin{array}{c}\text { Second year } \\
\text { postretrofit } \\
\mathrm{NAC}^{\mathrm{a}}\end{array}$ & $\begin{array}{c}\text { Second year } \\
\text { postretrofit } \\
\text { gross energy } \\
\text { savings }^{\mathrm{a}}\end{array}$ \\
\hline Tacoma participants (44) & 25,544 & 23,346 & 2,198 \\
\hline Tacoma nonparticipants (201) & 24,971 & 25,471 & -500 \\
\hline Idaho Falls participants (35) & 28,827 & 25,807 & 3,029 \\
\hline Idaho Falls nonparticipants (96) & 27,671 & 27,970 & -299 \\
\hline Eugene participants (41) & 21,708 & 20,330 & 1,378 \\
\hline Eugene nonparticipants (149) & 18,199 & 19,272 & $-1,073$ \\
\hline Elmhurst participants (40) & 27,470 & 26,584 & 886 \\
\hline Elmhurst nonparticipants (36) & 24,849 & 26,034 & $-1,185$ \\
\hline Vera participants (30) & 26,521 & 25,916 & 605 \\
\hline Vera nonparticipants (52) & 25,797 & 29,515 & $-3,718$ \\
\hline Richland participants (31) & 27,083 & 25,758 & 1,325 \\
\hline Richland nonparticipants (96) & 25,177 & 24,984 & 193 \\
\hline Snohomish participants (31) & 25,335 & 23,586 & 1,749 \\
\hline Snohomish nonparticipants (58) & 20,497 & 20,172 & 325 \\
\hline
\end{tabular}

${ }^{a}$ Electricity consumption and savings are reported in units of $\mathrm{kWh}$.

Table 4.4 shows gross energy savings by utility for the third year following weatherization. The results for the third postretrofit year are nearly identical to the results for the first and second years after weatherization.

Net energy savings are calculated by subtracting gross savings experienced by nonparticipants from gross savings achieved by participants. Taking the difference between gross savings by these two groups is intended to control for any exogenous influences (such as higher energy prices) that might influence energy behavior by all customers, in order to isolate the effect of the RWP on participants' energy use. Net savings by utility for all postretrofit years, along with the size of these savings in relation to preretrofit NAC, are given in Table 4.5. All seven utilities experienced net savings during the first postretrofit 
Table 4.4. Average weather-adjusted electricity consumption and gross electricity savings three years after weatherization, by utility

\begin{tabular}{lccc}
\hline $\begin{array}{c}\text { Utility } \\
\text { (no. of households) }\end{array}$ & $\begin{array}{c}\text { Preretrofit } \\
\text { NAC }^{\mathbf{a}}\end{array}$ & $\begin{array}{c}\text { Third year } \\
\text { postretrofit } \\
\text { NAC }\end{array}$ & $\begin{array}{c}\text { Third year } \\
\text { postretrofit } \\
\text { gross energy }^{\text {savings }^{\mathbf{a}}}\end{array}$ \\
\hline Tacoma participants (44) & & & \\
Tacoma nonparticipants (201) & 25,544 & 23,789 & 1,755 \\
Idaho Falls participants (35) & 24,971 & 25,376 & -405 \\
Idaho Falls nonparticipants (96) & 27,671 & 26,711 & 2,116 \\
Eugene participants (41) & 21,708 & 28,214 & -543 \\
Eugene nonparticipants (149) & 18,199 & 19,822 & 1,886 \\
Elmhurst participants (40) & 27,470 & 19,406 & $-1,207$ \\
Elmhurst nonparticipants (36) & 24,849 & 26,410 & 1,060 \\
Vera participants (30) & & 25,333 & -484 \\
Vera nonparticipants (52) & 26,521 & 26,072 & 449 \\
Richland participants (31) & 25,797 & 25,616 & 181 \\
Richland nonparticipants (96) & 25,177 & 24,103 & 2,980 \\
Snohomish participants (31) & 25,335 & 24,442 & 735 \\
Snohomish nonparticipants (58) & 20,497 & 25,101 & 2,34 \\
\hline
\end{tabular}

${ }^{a}$ Electricity consumption and savings are reported in units of $\mathrm{kWh}$.

year. In five cases in the first postretrofit year, the finding of a net savings was significant at the .10 level or less (often much less); in the other two cases, the finding was not significant. For those utilities where savings were found to be significant, they ranged from $2,387 \mathrm{kWh}$ ( $8.7 \%$ of previous energy use) to $4,338 \mathrm{kWh}$ (20\% of prior use).

Savings for the second postretrofit year are also shown in Table 4.5. It should be roted that the savings shown here for many of the utilities are substantially different from the first year savings. For the second year following weatherization, all utilities again showed a net savings. This finding is not significant for two utilities in the table. For those utilities with significant net savings, the range was from $10.6 \%$ to $16.3 \%$ of precetrofit NAC. 
Table 4.5. Average net electricity savings by utility

\begin{tabular}{lcccc}
\hline $\begin{array}{c}\text { Utility } \\
\text { (no. of households) }\end{array}$ & $\begin{array}{c}\text { Preretrofit } \\
\text { NAC }\end{array}$ & $\begin{array}{c}\text { First year } \\
\text { postretrofit } \\
\text { net energy } \\
\text { savings }\end{array}$ & $\begin{array}{c}\text { Second year } \\
\text { postretrofit } \\
\text { net energy } \\
\text { savings }\end{array}$ & $\begin{array}{c}\text { Third year } \\
\text { postretrofit } \\
\text { net energy } \\
\text { savings }\end{array}$ \\
\hline Tacoma (44) & 25,544 & 2,608 & 2,698 & 2,160 \\
& 28,827 & $(10.2)^{*}$ & $(10.6)^{*}$ & $(8.5)^{* *}$ \\
Idaho Falls (35) & 3,457 & 3,319 & 2,659 \\
Eugene (41) & $(12.0)^{*}$ & $(11.5)^{*}$ & $(9.2)^{*}$ \\
Elmhurst (40) & 21,708 & 4,338 & 2,451 & 3,093 \\
& & $(20.0)^{*}$ & $(11.3)^{*}$ & $(14.2)^{*}$ \\
Vera (30) & 27,470 & 2,388 & 2,071 & 1,544 \\
& & $(8.7)^{* *}$ & $(7.6)^{* *}$ & $(5.6)^{* * *}$ \\
Richland (31) & 26,521 & 3 & 4,323 & 268 \\
& & $(0.0)$ & $(16.3)^{*}$ & $(1.0)$ \\
Snohomish (31) & 27,083 & 2,781 & 1,132 & 2,245 \\
& & $(10.3)^{*}$ & $(4.2)$ & $(8.3)^{* *}$ \\
& & 1,480 & 1,424 & 1,518 \\
& & $(5.8)$ & $(5.6)$ & $(6.0)^{* * *}$ \\
\hline
\end{tabular}

Using two-tail t-test comparing gross savings for participants and nonparticipants, net savings are statistically significantly different from zero at ${ }^{*}=.001,{ }^{* *}=.01,{ }^{* * *}=.1$. Numbers in parentheses are percentage savings.

Savings for the third postretrofit year resemble savings from the first postretrofit year (Table 4.5). All utility net savings except for Vera are significant at the .10 level. During the third postretrofit year, Eugene saved more than $14 \%$ of preretrofit energy use, and Idaho Falls saved nearly $10 \%$.

Table 4.6 represents an attempt to explain some of the large differences in savings observed among the utilities studied. First, second, and third year net savings are listed for each utility, along with three potentially important characteristics of each service area that might help explain the variance in savings achieved by utility customers. These characteristics are the average per capita income in the county served by each utility, the magnitude of any 
Table 4.6. Average net electricity savings and possible explanatory factors, by utility

\begin{tabular}{|c|c|c|c|c|c|c|}
\hline Utility & $\begin{array}{l}\text { 1st year net } \\
\text { savings as } \% \\
\text { of pre- } \\
\text { retrofit } \\
\text { NAC }\end{array}$ & $\begin{array}{l}\text { 2nd year net } \\
\text { savings as } \% \\
\text { of pre- } \\
\text { retrofit } \\
\text { NAC }\end{array}$ & $\begin{array}{l}\text { 3rd year net } \\
\text { savings as } \% \\
\text { of pre- } \\
\text { retrofit } \\
\text { NAC }\end{array}$ & $\begin{array}{l}\text { Average } \\
\text { per capita } \\
\text { inconie }^{1}\end{array}$ & $\begin{array}{c}\text { Recent } \\
\text { rate } \\
\text { change }\end{array}$ & $\begin{array}{c}\text { Long-run } \\
\text { average } \\
\text { HDD }^{3}\end{array}$ \\
\hline Eugene & $\begin{array}{r}4,338 \\
(20.0)\end{array}$ & $\begin{array}{r}2,451 \\
(11.3)\end{array}$ & $\begin{array}{r}3,093 \\
(14.2)\end{array}$ & $\$ 7,819$ & 0 & 3,484 \\
\hline Tacoma & $\begin{array}{r}2,608 \\
(10.2)\end{array}$ & $\begin{array}{r}2,698 \\
(10.6)\end{array}$ & $\begin{array}{r}2,160 \\
(8.5)\end{array}$ & $\$ 7,417$ & $\$ .0052$ & 3,684 \\
\hline Idaho Falls & $\begin{array}{r}3,457 \\
(12.0)\end{array}$ & $\begin{array}{r}3,319 \\
(11.5)\end{array}$ & $\begin{array}{r}2,659 \\
(9.2)\end{array}$ & $\$ 7,170$ & 0 & 6,693 \\
\hline Elmhurst & $\begin{array}{r}2,388 \\
(8.7)\end{array}$ & $\begin{array}{r}2,071 \\
(7.6)\end{array}$ & $\begin{array}{r}1,544 \\
(5.6)\end{array}$ & $\$ 7,409$ & $\$ .0008$ & 3,684 \\
\hline Richland & $\begin{array}{r}2,781 \\
(10.3)\end{array}$ & $\begin{array}{r}1,132 \\
(4.2)\end{array}$ & $\begin{array}{r}2,245 \\
(8.3)\end{array}$ & $\$ 9,837$ & 0 & 3,651 \\
\hline Snohomish & $\begin{array}{r}1,480 \\
(5.8)\end{array}$ & $\begin{array}{r}1,424 \\
(5.6)\end{array}$ & $\begin{array}{r}1,518 \\
(6.0)\end{array}$ & $\$ 8,243$ & $\$ .016$ & 3,884 \\
\hline Vera & $\begin{array}{r}3 \\
(0.0)\end{array}$ & $\begin{array}{r}4,323 \\
(16,3)\end{array}$ & $\begin{array}{r}268 \\
(1.0)\end{array}$ & $\$ 6,932$ & 0 & 5,599 \\
\hline
\end{tabular}

'Source for per capita incrime is the 1980 (ensus of population. 1985.

${ }^{2}$ Recent rate (hinges are increases Ihat tonk plaw between June 1984 and December

${ }^{3} \mathrm{HDD}$ are based on a reference temperalure of $60^{\circ} \mathrm{F}$.

recent increases in electricity rates, and the severity of the local climate as represented by long-run average heating degree days.

An examination of the data presented in Table 4.6 shows no obvious relationship between net savings and any of the independent variables. In all years, for example, Eugene had significantly higher savings levels than Elmhurst, but both had virtually identical climates and in evels. Those utilities with recent changes in their electricity rates showed varying levels of energy savings. 


\subsection{OVERALL PROGRAM SAVINGS}

After household energy use was aggregated by utility and net savings were calculated, utility-level data were further aggregated to allow the calculation of programwide savings. Average electricity consumption and end-use estimates for the preretrofit year and the three postretrofit years are shown in Fig. 4.3.

Unweighted and weighted calculations of savings were made, yiclding substantially different results. Unweighted savings were calculated by averaging the mean savings achieved by each utility, which gave the smallest and largest utilities equal weight. In contrast, weighted savings (as explained in Section 2.4) were calculated by attaching a different weight to the savings achieved by each utility, based on the proportion of total program participants (from all seven utilities combined) contributed by each utility. By weighting the savings of each utility in this manner, a more accurate representation of programwide savings can be made.

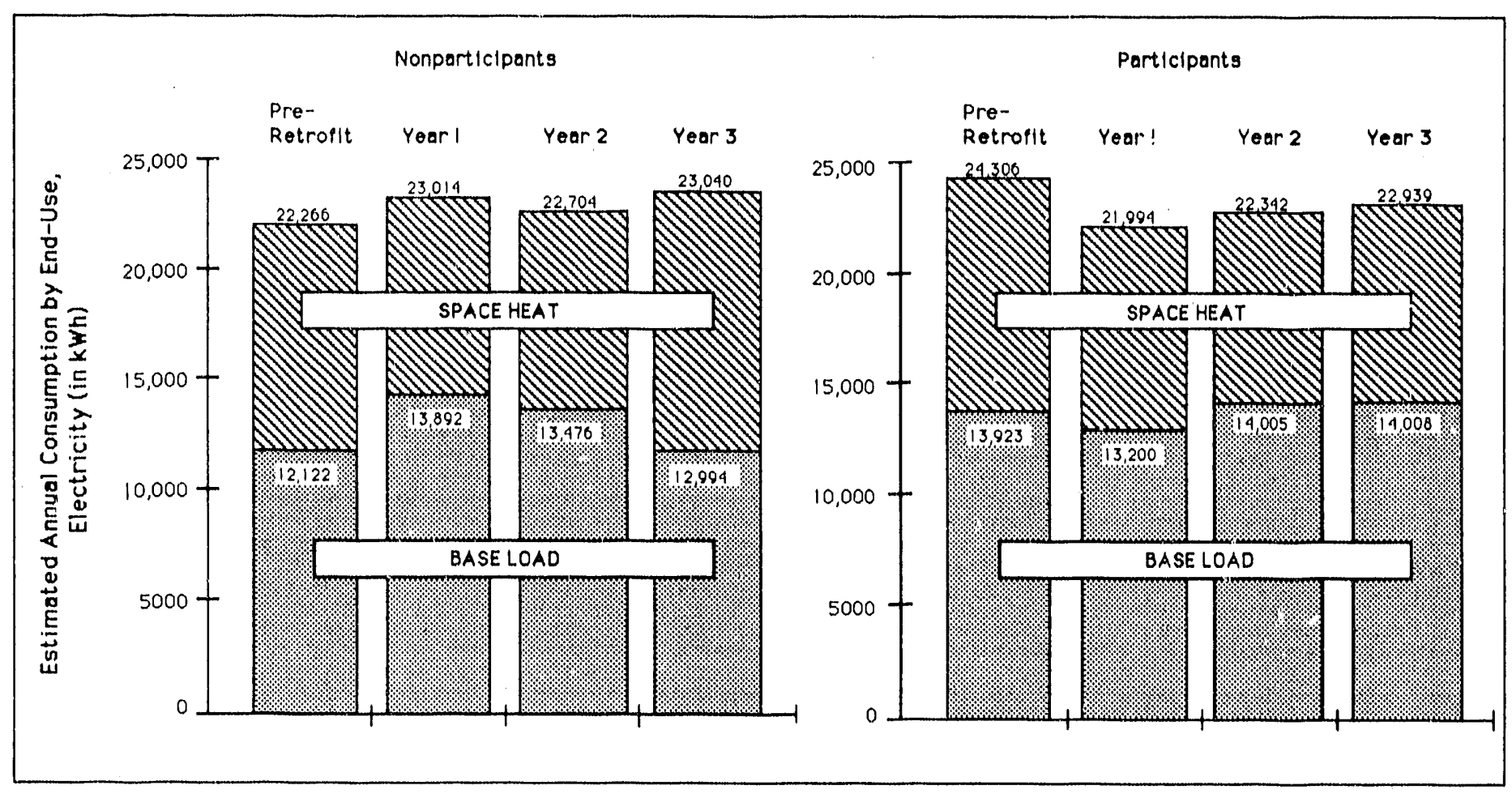

Fig. 4.3. NAC components for program participants and nonparticipants. 
Table 4.7 shows unweighted energy savings achieved by participants and nonparticipants one, two, and three years after weatherization. As explained earlier, gross savings by nomparticipants were suttracted from participants' gross savings to yield net savings due to program participation. Unweighted annual net savings one, two, and three years after weatherization were $2,670 \mathrm{kWh}, 2,327 \mathrm{kWh}$, and $1,997 \mathrm{kWh}$, respectively, representing $10 \%$, $9 \%$, and $8 \%$ of preretrofit energy use. The finding of a positive net savings was significant at the .01 level in all three years. The estimates of space-heat energy use shown in this table do not change significantly over the three years.

A more representative picture of overall program accomplishments is provided by showing weighted energy savings. Figure 4.4 graphically illustrates weighted gross savings by participants and nonparticipants one, two, and three years after weatherization. In Table 4.8, both weighted gross savings and net savings for all postretrofit years are shown. Programwide

Table 4.7. Average electricity savings for program participants and nonparticipants (unwcighted)

\begin{tabular}{|c|c|c|c|c|c|c|}
\hline & & $\begin{array}{l}\text { Pre- } \\
\text { retrofit } \\
\text { NAC }\end{array}$ & $\begin{array}{c}\text { Total } \\
\text { gross } \\
\text { savings } 1\end{array}$ & $\begin{array}{c}\text { Total } \\
\text { net } \\
\text { savings }^{2}\end{array}$ & $\begin{array}{l}\text { Total net } \\
\text { savings as' } \\
\% \text { of pre- } \\
\text { retrofit } \\
\text { NAC }\end{array}$ & $\begin{array}{c}\text { Test of } \\
\text { research } \\
\text { hypothesis } \\
\text { that total } \\
\text { net saving } \\
>0\end{array}$ \\
\hline $\begin{array}{l}\text { One year } \\
\text { after }\end{array}$ & Participants & 25,961 & $\begin{array}{r}1,928 \\
(1,535)\end{array}$ & $\begin{array}{r}2,670 \\
(1,372)\end{array}$ & $10.3 \%$ & $\mathrm{p}<.01$ \\
\hline $\begin{array}{l}\text { weather- } \\
\text { ization }\end{array}$ & $\begin{array}{l}\text { Non- } \\
\text { participants }\end{array}$ & 23,589 & $\begin{array}{r}-742 \\
(163)\end{array}$ & -- &.- & \\
\hline $\begin{array}{l}\text { Two years } \\
\text { after }\end{array}$ & Participants & 25,961 & $\begin{array}{r}1,618 \\
(1,573)\end{array}$ & $\begin{array}{r}2,327 \\
(1,523)\end{array}$ & $9.0 \%$ & $p<.01$ \\
\hline $\begin{array}{l}\text { weather- } \\
\text { ization }\end{array}$ & $\begin{array}{l}\text { Non- } \\
\text { participants }\end{array}$ & 23,589 & $\begin{array}{r}-709 \\
(50)\end{array}$ & -- & -- & \\
\hline $\begin{array}{l}\text { Three years } \\
\text { after }\end{array}$ & Participants & 25,961 & $\begin{array}{r}1,524 \\
(1,731)\end{array}$ & $\begin{array}{r}1,997 \\
(1,540)\end{array}$ & $7.7 \%$ & $\mathrm{p}<.01$ \\
\hline $\begin{array}{l}\text { weather- } \\
\text { ization }\end{array}$ & $\begin{array}{l}\text { Non- } \\
\text { participants }\end{array}$ & 23,589 & $\begin{array}{r}-473 \\
(191)\end{array}$ & -- & -- & \\
\hline
\end{tabular}

${ }^{1}$ Numbers in parentheses are estimates of gross space-heating savings, in $\mathrm{kWh}$.

${ }^{2} \mathrm{Numbers}$ in parentheses are estimates of net space-heating savings, in $\mathrm{kWh}$. 


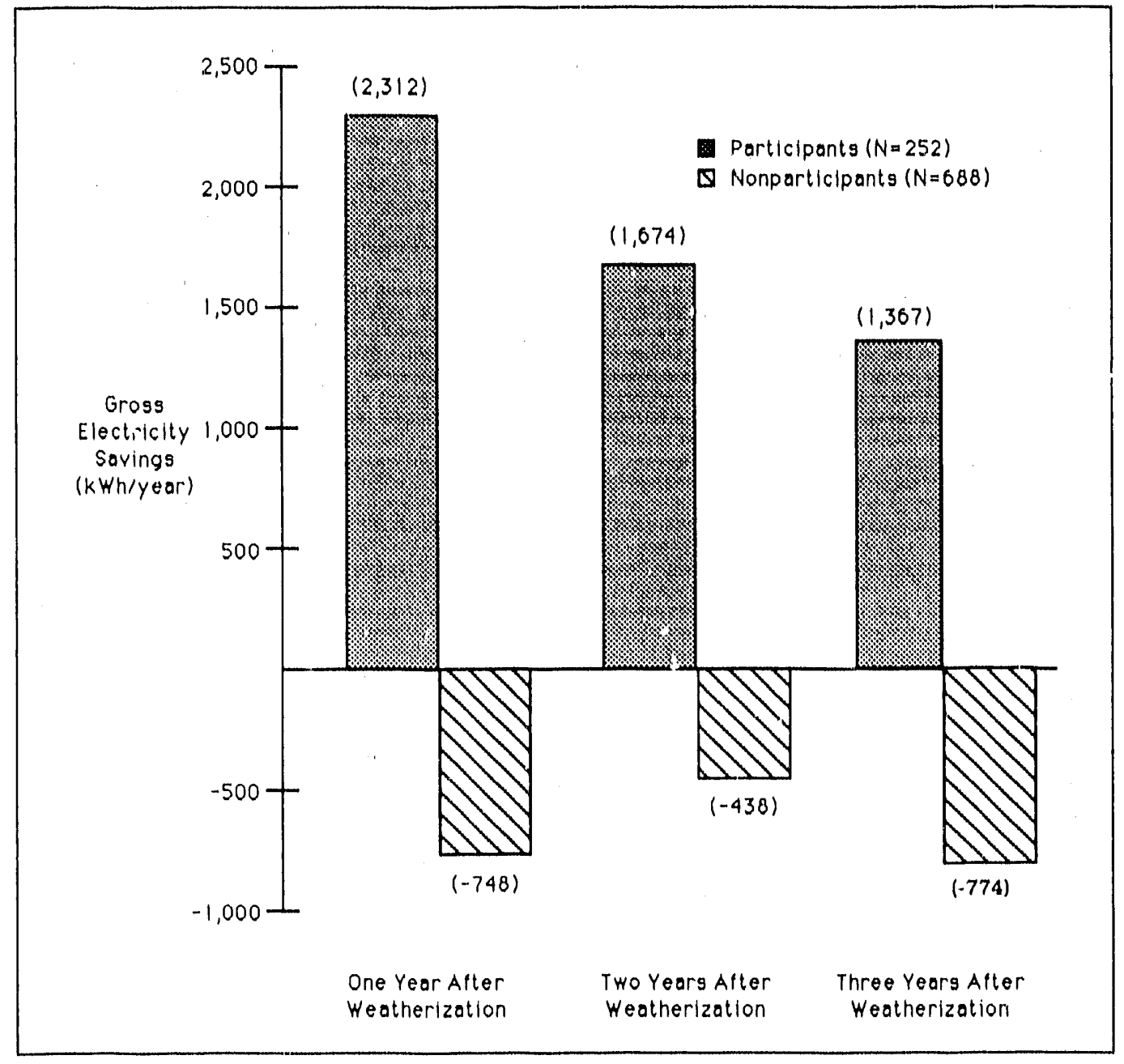

Fig. 4.4. Average programwide gross electricity savings for program participants and nonparticipants (weighted). 
Table 4.8. Weighted average annual program induced gross and net electricity savings for all postretrofit years

\begin{tabular}{|c|c|c|c|c|c|c|}
\hline & & $\begin{array}{c}\text { Pre- } \\
\text { weatherization } \\
\text { energy use }\end{array}$ & $\begin{array}{l}\text { Total } \\
\text { gross } \\
\text { savings } 1\end{array}$ & $\begin{array}{c}\text { Total } \\
\text { net } \\
\text { savings }^{2}\end{array}$ & $\begin{array}{c}\text { Total net } \\
\text { savings as } \\
\% \text { of pre- } \\
\text { weather- } \\
\text { ization } \\
\text { energy use }\end{array}$ & $\begin{array}{c}\text { Test of } \\
\text { research } \\
\text { hypothesis } \\
\text { that total } \\
\text { net savings } \\
>0\end{array}$ \\
\hline $\begin{array}{l}\text { One year } \\
\text { after }\end{array}$ & Participants & $24,3() 6$ & $\begin{array}{r}2,312 \\
(1,588)\end{array}$ & $\begin{array}{r}3,060) \\
(1,224)\end{array}$ & $12.6 \%$ & $\mathrm{p}<.01$ \\
\hline $\begin{array}{l}\text { weather- } \\
\text { ization }\end{array}$ & $\begin{array}{l}\text { Non- } \\
\text { participants }\end{array}$ & 22,266 & $\begin{array}{r}-748 \\
(364)\end{array}$ & -- & -. & \\
\hline $\begin{array}{l}\text { Two years } \\
\text { after }\end{array}$ & Participants & 24,306 & $\begin{array}{r}1,674 \\
(1,756)\end{array}$ & $\begin{array}{l}2,112 \\
(840)\end{array}$ & $8.7 \%$ & $p<.01$ \\
\hline $\begin{array}{l}\text { weather- } \\
\text { ization }\end{array}$ & $\begin{array}{l}\text { Non- } \\
\text { participants }\end{array}$ & 22,266 & $\begin{array}{r}-438 \\
(916)\end{array}$ & .. & -. & \\
\hline $\begin{array}{l}\text { Three years } \\
\text { after }\end{array}$ & Participants & $24,3(16$ & $\begin{array}{r}1,367 \\
(1,452)\end{array}$ & $\begin{array}{r}2,141 \\
(1,354)\end{array}$ & $8.9 \%$ & $p<.01$ \\
\hline $\begin{array}{l}\text { weather- } \\
\text { ization }\end{array}$ & $\begin{array}{l}\text { Non- } \\
\text { participants }\end{array}$ & 22,266 & $\begin{array}{l}-774 \\
(98)\end{array}$ & .. & -. & \\
\hline
\end{tabular}

${ }^{1}$ Numbers in parentheses are estimates of gross space-heating savings, in $\mathrm{kWh}$.

${ }^{2}$ Numbers in parentheses are estimates of net space-heating savings, in kWh.

total net savings were $3,(66) \mathrm{kWh}, 2,112 \mathrm{kWh}$, and 2,141 , respectively, one, two, and three years following weatherization. For the first year, these savings represent $13 \%$ of preretrofit energy use (Table 4.8). Average net savings two years after weatherization were $9 \%$ of prior use, and $9 \%$ three years after weatherization. As with unweighted savings, the finding of a positive net savings in all years was signilicant at the .01 level.

As shown in Tables 4.7 and 4.8 and discussed in the text, there is some difference between weighted and unweighted total net savings. When weighted and unweighted savings do differ from each other, the weighted numbers present a more representative picture of overall programwide savings.

A sense of the magnitude of electricity savings achieved by 1986 Long-Term RWP participants for three years after weatherization can be attained by comparing the amount of energy saved by this group with the savings experienced by previous participants in this and 
similar Bonneville conservation programs. Table 4.9 and Figure 4.5 show net savings for participants in the RWP Pilot, Interim, and Long-Term programs, whose homes were weatherized between 1981 and 1986. For the Pilot Program, the savings presented are for the lirst three years following weatherization. For 1982 and 1983 participants in the Interim Program, savings estimates are available for three and two years after participation, respectively. For the Long-Term RWP, the savings experienced by 1985 and 1986 participants are tracked for three postweatherization years.

There had been a downward trend over the years in the savings achicved in the first postrelrofit year by each successive cohort of participants, ranging from $3,840 \mathrm{kWh}$ in 1981 to $2,610 \mathrm{kWh}$ in 1985 . Contrary to this trend, the 1986 group had higher savings than the 1985 group in its first postretrofit year. Recall that the audit-estimated savings for 1986 Long-Term RWP participants were also greater than for the 1985 or 1983 participants.

Three of the four cohorts discussed above exhibit marked decay in savings over time, including the 1986 cohort. Net savings by the 1985 cohort remained relatively constant for three years after retrofit. In contrast, the amount of energy saved by the 1986 group fell by nearly $31 \%$ from the first to the second postretrofit year. However, savings did not continue to decline at that rate. Savings increased by $2 \%$ from the second to the third postretrofit year so that the average annual decline after the first postretrofit year was approximately $15 \%$.

Table 4.9. Average annual electricity savings during postretrofit years

\begin{tabular}{lccc}
\hline & \multicolumn{3}{c}{ Net Encrgy Savings $(\mathrm{kWh} /$ Year) } \\
\cline { 2 - 4 } & Year 1 & Year 2 & Year 3 \\
\hline Pilot (1980-82) & 3,840 & 3,790 & 3,410 \\
Interim (1982-83) & 4,200 & 3,600 & 2,500 \\
Long Term (1985) & 2,610 & 2,565 & 2,600 \\
Long Term (1986) & 3,060 & 2,112 & 2,140 \\
\hline
\end{tabular}

${ }^{1}$ Does not include $7.5 \%$ credit for reduced transmission and distribution losses.

${ }^{2}$ Net energy savings of the Interim Program is the weigl.ted average of the 1982 and 1983 cohort savings. In particular:

Year $1=.483(4,100)+.517(4,3(0))=4,200$

Year $2=.483(3,300)+.517(3,800)=3,600)$

The 1982 cohort is the only cohort with a third year of savings $(2,50(0)$ ). 


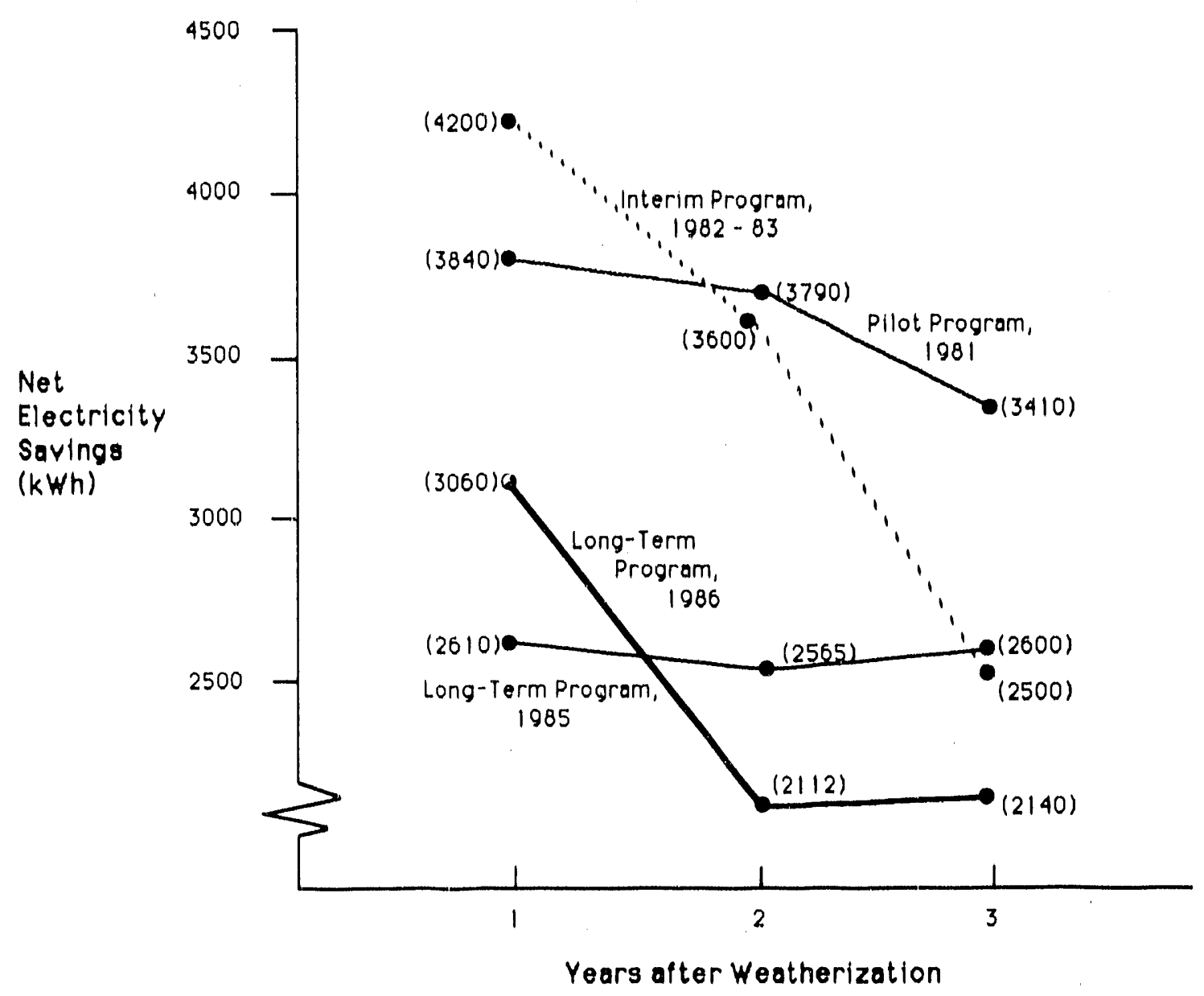

Fig. 4.5. Comparison of electricity savings by participants in Bonneville's weatherization prograñis.

While the causes of inconsistency in conservation over time are still unclear, there is a growing body of empirical evidence documenting the magnitude of conservation decay. Longitudinal evaluations of Seatlle City Light's Home Energy Loan Program (HELP) and Utah's Institutional Conservation Program (ICP) are particularly noteworthy.

Sumi and Coates (1988) examined HELP to determine the persistence of energy savings over the 1982-87 period. The analysis was restricted to 1,030 single-family households who had received a loan, performed a home weatherization, and who had lived in the same home for the duration of the study period. A nonparticipant sample of 229 homes was 


\section{$35 / 36$}

studied for comparison purposes. All energy consumption data were weather-normalized using PRISM. On average it was found that the energy saved by participating households declined $5.9 \%$ per year, or $27 \%$ over the six-year period.

The analysis of Utah's ICP examined forty buildings that were retrofitted in the early 1980's. Energy use for each building was normalized using building area and weather factors, but no comparison group of buildings was studied. It was estimated that the energy savings realized immediately after retrofit were declining at an average rate of $6.9 \%$ per year (Utah Energy Office, 1989).

The overall experience with Bonneville's weatherization efforts suggests a larger conservation decay than for the Seattle and Utah programs discussed above. The average decline in net savings for the eight one-year segments shown in Figure 4.5 is $10.3 \%$.

In addition to calculating total savings, an estimate was made, using the PRISM model, of the portion of total savings that came from reductions in energy used for space heating. The outcomes of this analysis are open to question because of known biases in the space-heating estimates from PRISM (Hwang, 1989), and several large, inexplicable shifts from year to year in the reference temperature used to estimate space-heat encrgy use. The results are displayed in Fig. 4.3, p. 29. Slightly under two-thirds of the first-year gross energy savings of program participants resulted from reductions in space-heat electricity usage. In the second and third years, space-heat savings accounted for virtually all of the gross savings, as anticipated. For nonparticipants, the PRISM results suggest that the eventual increased usage in the third postretrofit year came from increased space-heat energy use while baseload usage approached the preretrofit level.

In the third postretrofit year, all except three kWh of the participants' change in electricity use occurred in space-heat energy use; the baseload was constant from the second to the third postretrofit year. For nonparticipants, baseload declined by $4 \%$ but space heating increased by $9 \%$ from the second to the third postretrofit year; space heating for the participants increased by $7 \%$. 


\section{SUMMARY AND CONCLUSIONS}

In the original report, it was shown that audit-estimated savings for 1986 Long-Term participants were not substantially different from those of participants of the Pilot, Interim, or 1985 Long-Term RWP programs. However, the average total cost per retrofit job increased significantly over the same five-year period. As a result, the average total cost per $\mathrm{kWh}$ of estimated savings has increased markedly. In contrast, Bonneville's costs per $\mathrm{kWh}$ of audit-estimated savings have remained fairly stable because of greater cost sharing by utilities and participating households in recent years.

In $1986,83 \%$ of the recommended measures were installed by the program, approximately the same percentage as in previous years. The weighted rate of installation (i.e., each installed recommendation was weighted by its audit-estimate in $\mathrm{kWh} / \mathrm{year}$ ) was somewhat greater $(89 \%)$. Thus, 1986 participants were more likely to install measures with the greatest audit-estimated potential for savings - a pattern that was found in evaluations of the Bonneville programs noted above.

For the RWP overall, savings experienced by 1986 participants were substantial. During the first postretrofit year, weighted net savings averaged $3,060 \mathrm{kWh}$, or $12.6 \%$ of the previous year's energy consumption. In the second postretrofit year, a weighted average of $2,112 \mathrm{kWh}$ was saved, amounting to $9.0 \%$ of preretrofit energy use. In the third postweatherization year, a net weighted average of $2,140 \mathrm{kWh}$ was saved, $9 \%$ of preweatherization electricity use. After 'he first postweatherization year program electricity savings declined by an average of $15 \%$ per year; savings declined by almost $31 \%$ in the second postretrofit year and edged upward by $2 \%$ in the third postretrofit year.

As shown in Chapter 4, the average amount of energy saved at the household level was positive for 1986 participants and negative for nonparticipants. Despite this general relationship between program participation and savings, the actual amount of energy saved by participating households varied widely and was not closely related to audit-estimated savings. Relatively little of the variation in household performance was explained by preretrofit energy use, total weatherization costs, climate, and the installation of various energy conservation measures. This indicates that other factors, such as family composition and income, structural characteristics, changes in thermostat settings, and changes in the use 
of supplemental heat sources over time, may be important in determining the outcomes of residential energy conservation programs.

At the utility level, average gross savings for the 1986 cohort were always positive for participants and mostly negative for nonparticipants. Statistically significant net savings were achieved by over half of the utilities studied during all three postretrofit years. While substantial differences were observed among utilities in the amount of energy saved, these could not be explained by differences in average per capita income, recent changes in electricity rates, or climatic conditions (represented by long-run heating degree days). In addition to differences between utilities, substantial differences were also identified within utilities in terms of the amount of energy saved from one year to the next. The magnitude of net savings fluctuated by more than $30 \%$ from the first to the second postretrofit year for four of the seven utilities in our updated sample. To help explain between-utility variation, additional research could examine differences among utilities in their administration of the RWP as well as in the populations they serve. Within-utility variations over time could be addressed by studying the household characteristics, structural conditions, and occupant behavior of households with marked deviations between predicted and actual savings.

In one respect, the decline experienced by the 1986 group in programwide savings from the first to the third postretrofit year represents a departure from the experience of the 1985 cohort. However, both cohorts show an increase in third postretrofit-year savings over second year declines, and they are consistent with the levels of conservation decay documented for earlier participants in the Pilot and Interim Programs.

The observed decline in savings for the 1986 Long-Term RWP appears to be a durable short-term phenomenon. The observed decline in savings appears to "bottom out" after two years. Consequently, without further research, the third year savings are the best predictor of program-induced energy savings. It might be useful to extend the evaluation of savings to four and five years after retrofit. At the same time, research should be undertaken to explain the observed levels of conservation decay. This research would require home inspections as well as interviews with participants.

The research should also include the tracking of participants and nonparticipants who move during the study period. To date, analysis biases associated with sample attrition and data quality screenit g have not significantly affected program evaluations. However, extended analyses would be affected. For instance, the 252 participant houscholds retained for analysis 


\section{0}

three years after weatherization did spend slightly more $(6.5 \%)$ of their own money in retrofit measures than the 93 households removed from analysis. This suggests that the households retained in the analysis are willing to make larger investments in conservation. Thus, actual program-induced energy savings may be overestimated in an extended analysis.

Since 1981, energy savings have declined and costs have risen for each subsequent stage (Pilot, Interim, and Long-Term) of the Residential Weatherization Program. An earlier analysis of changes in the RWP over time (Hirst and Keating 1987) suggests that this reduction in savings is the result of a number of factors, including fuel prices, changes in the region's economy, public awareness of energy issues, and increasing adoption of conservation measures prior to participation in the Bonneville program. The degradation of weatherization materiais over time and poor maintenance practices may also contribute to conservation decay. Despite the drop in the amount of energy saved from one year to the next, the energy savings and associated costs identified for the 1986 cohort of the Long-Term RWP indicate that significant savings can still be achieved at least through the third postretrofit year. 


\section{APPENDIX A}

\section{BIAS TESTS}

As indicated in Chapter 2, data were processed and screened in accordance with predetermined criteria. Households were removed from the original analysis when any of the following Conditions were true:

1. The occupant was defined as a low-income participant, the housing type was either multifamily or attached, or the house had previously been included in another weatherization program; or

2. The retrofit work performed under the 1986 Long-Term RWP was conducted before April 1 or after scptember 30; or

3. Either the utility's weatherization worksheet or NAC was unavailable for a participant, or the NAC was not available for a nonparticipant (e.g., households moved).

Table A.1 shows the distribution of participating and nonparticipating houses across the above Conditions.

A series of tests was conducted to determine whether the data screening method introduced bias into the analysis results reported in Chapter 4. Comparisons of means were conducted on all available data. Factors like climate and distribution of households across utilities at different screening stages were also examined. The potential bias associated with Condition 1 was not assessed. Since the houses removed from analysis under Condition 1 did not fit the description of the sampling frame for this study, there is no conceptual bias.

In the bias test for Condition 2, the 596 participant households removed from the sample were compared to the 513 that remained (see Table A.1). Climate zones and utilities were similarly represented in both groups. It was found that the two groups of households were not significantly different in terms of utility and Bonneville retrofit costs and retrofit activity, but that the 513 households remaining in the sample contributed $10 \%$ more to their respective retrofit costs than the 596 households that were dropped. Thus, our estimate of the average level of customer contribution to the total retrofit costs may be slightly high.

In the bias test for Condition 3 for participants, 345 participant households were compared to the 513 households from the previous step and to the 168 households dropped 
Table A.1. Data attrition and sample sizes (program summary)

\begin{tabular}{|c|c|c|c|c|c|c|}
\hline & \multirow[t]{3}{*}{ Universe } & \multicolumn{5}{|c|}{ Conditions $^{\mathrm{a}}$} \\
\hline & & 1 & 2 & 3 & 3 & 3 \\
\hline & & & & $\begin{array}{c}\text { (1 year } \\
\text { after } \\
\text { weather- } \\
\text { ization) }\end{array}$ & $\begin{array}{c}\text { (2 years } \\
\text { after } \\
\text { weather- } \\
\text { ization) }\end{array}$ & $\begin{array}{c}\text { (3 years } \\
\text { after } \\
\text { weather- } \\
\text { ization) }\end{array}$ \\
\hline A. Participants & 1502 & $\begin{array}{r}393 \\
(1109)\end{array}$ & $\begin{array}{r}596 \\
(513)\end{array}$ & $\begin{array}{r}168 \\
(345)\end{array}$ & $\begin{array}{r}30 \\
(315)\end{array}$ & $\begin{array}{r}63 \\
(252)\end{array}$ \\
\hline B. Nonparticipants & 1339 & - & - & $\begin{array}{r}344 \\
(995)\end{array}$ & $\begin{array}{r}140 \\
(855)\end{array}$ & $\begin{array}{r}167 \\
(688)\end{array}$ \\
\hline
\end{tabular}

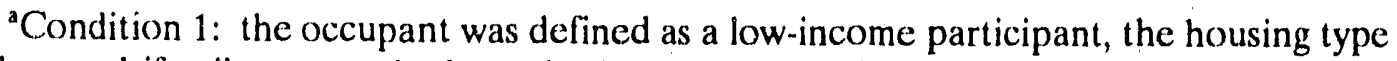
was either multifamily or attached, or the house had previously been included in another weatherization program. Condition 2: the retrofit work performed under the 1986 LongTerm RWP was conducted before April 1 or after September 30. Condition 3: either the utility's weatherization worksheet or NAC was unavailable for a participant, or the NAC was not available for a nonparticipant (e.g., households moved). The top number of each pair is the number of houses that were removed from analysis. The bottom number (in parentheses) refers to the houses that were retained.

at this stage. In terms of utility and Bonneville retrofit costs and retrofit activity, these three groups were not different.

This bias test was replicated for the 315 households with sufficient data to allow identification of savings two years after weatherization. In terms of customer and total retrofit costs, and the number of retrofit measures installed, the 315 houscholds retained in the two-years-after analysis were more active in the 1986 program than the 198 households that were eliminated by our screening criteria.

Customer costs for the houses retained in the two-years-after analysis were approximately $23 \%$ higher than the customer costs of the houses for which NACs were not available and which were dropped from the analysis. Total retrofit costs were approximately $10 \%$ higher. The impacts of this bias on our estimates of energy savings, if any, are unclear. However, the difference in customer costs suggests that those households that may have been planning to move made smaller personal investments in the retrofits than those who remained in their residences. 


\section{$43 / 44$}

Households dropped from year two to year three are not different from those retained in terms of preretrofit energy use, retrofit cost, and distribution across weather zone and utility.

For the nonparticipants, the bias test on Condition 3 revealed that the climate zones and utilities were similarly represented before and after removing houses due to the screening criteria.

In the present study of households with four years of data, several comparisons of group means revealed that there are no program-level differences between households with only two years of data and the households retained in this update. A t-test of the differences between means was conducted on several variables including preretrofit energy use, first-year savings, audit-estimated savings, and retrofit activity. The 252 participating households with four years of data were nearly identical to the $\mathbf{3 4 5}$ households with only two years of data.

Customer weatherization costs were approximately $6.5 \%$ higher for the sample of 252 households than for the sample of 345 houstholds. This difference in customer investment in residential conservation was not statistically significant.

The sample of 688 control households estimated in this updated analysis was also not different from the sample of 995 households with two years of data. The means of preretrofit energy use were similar. The changes in energy use from the preretrofit year to the first year after retrofit were virtually identical. 


\section{ACKNOWLEDGMENTS}

This research was funded by the Office of Energy Resources, Bonneville Power Administration under the direction of Pam Brandis. Assistance with data collection was provided by ERCE (Portland, Oregon). Martin Schweitzer and Bruce Tonn conducted comprehensive reviews of early report drafts. Ethel Schorn was responsible for keyboarding the report, and Paige Tolson prepared the graphics and edited the final report draft. 


\section{REFERENCES}

Amir, E. and M. Ringer, 1987, Relative Cost of Electricity Production, California Energy Commission, Sacramento, California.

Bonneville Power Administration, 1980, Residential Weatherization Pilot Program, Portland, Oregon.

Bonneville Power Administration, 1982a, BPA Home Energy Efficiency Program, Residential Weatherization, Portland, Oregon, January.

Bonneville Power Administration, 1982b, Conservation Program Fact Sheet Residential Weatherization, Portland, Oregon, October.

Bonneville Power Administration, 1984a, Results of the BPA Residential Weatherization Pilot Program Evaluation, Office of Conservation, DE-2, Portland, Oregon, August.

Bonneville Power Administration, 1986, Office of Conservation 1986 Yearbook, Portland, Oregon.

Brandis, P. and B. Bronfman, 1987, "Captured Conservation: One Year of a Decade," Proceedings of the 1987 Conference, Energy Conservation Program Evaluation: Practical Methods, Useful Results, Volume 2, Argonne, Illinois: Argonne National Laboratory, pp. 435-444.

Brown, M. A. and D. L. White, 1988, "Stimulating Energy Conservation by Sharing the Savings: A Community-Bass:d Approach," Environment and Planning A, 20, pp. 517-534.

Eissler, A., 1984, personal communication, Bonneville Power Administration, Office of Conservation, Portland, Oregon, January.

Fels, M. F., 1986, "PRISM: An Introduction," Energy and Buildings, 9, pp. 5-18.

Fels, M. F., J. Rachlin, and R. H. Socolow, 1986, "Seasonability of Non-heating Consumption and Its Effect on PRISM Results," Energy and Buildings, 9, pp. 139-148.

Goeltz, R., E. Hirst, and D. Trumble, 1986, Electricity Savings One to Three Years After Participation in the BPA Residential Weatherization Program, ORNL/CON-194, Oak Ridge National Laboratory, Oak Ridge, Tennessee, April.

Goldberg, M. L., 1986, "A Midwest Low-Income Weatherization Program Seen Through PRISM," Energy and Buildings, 9, pp. 37-44.

Hacri, M. Hossein, 1988, Electricity Savings Three Years After Participation in the Bonneville Power Administration Regionwile Weatherization Program, ERC/PO-34, ERC International, Portland, Oregon. 
Hirst, E., B. Bronfman, R. Goeltz, J. Trimble, and D. Lerman, 1983a, Evaluation of the BPA Residential Weatherization Pilot Program, ORNL/CON-124, Oak Ridge National Laboratory, Oak Ridge, Tennessee, June.

Hirst, E., R. Goeltz, M. Thornsjo, and D. Sundin, 1983, Evaluation of the Home Energy Audit Retrofit Loan Programs in Minnesota: the Northern States Power Experience, ORNL/CON-136, Oak Ridge National Laboratory, Oak Ridge, Tennessee.

Hirst, E., D. Whitc, and R. Gocltz, 1985, Three Years After Participation: Electricity Savings Due to the BPA Residential Weatherization Program, ORNL/CON-166, Oak Ridge National Laboratory, Oak Ridge, Tennessee, January.

Hirst, E., R. Goeltz, D. White, B. Bronfman, D. Lerman, and K. Keating, 1985a, Evaluation of the BPA Residential Weatherization Program, ORNL/CON-180, Oak Ridge National Laboratory, Oak Ridge, Tennessee, June.

Hirst, E. and R. Goeltz, 1986, Electricity Use for Residential Space Heating: Comparison of the Princeton Scorekeeping Method with End-Use Load Data, ORNL/CON-203, Oak Ridge National Laboratory, Oak Ridge, Tennessee, April.

Hirst, E. and K. Keating, 1987, "Dynamics of Energy Savings Due to Conservation Programs," Energy Systems and Policy, 10(3), pp. 257-273.

Hirst, E., R. Goeltz, and D. Trumble, 1989, "Effects of the Hood River Conservation Project on Electricity Use," Energy and Buildings 13 (1), pp. 19-30.

Horowitz, M. J., B. H. Bronfman, and D. I. Lerman, 1987, Evaluation of the Bonneville Power Administration Long-Term Residential Weatherization Program: The Data Gathering Report, IEAL/PO-16, International Energy Associates Limited, Portland, Oregon.

Hwang, H. L., 1989, Analysis of the Princeton Scorekeeping Method Using End-Use Data From the Hood River Conservation Project Submetered Houses, ORNL/CON-270, Oak Ridge National Laboratory, Oak Ridge, Tennessee, March.

Pratt, F., 1984, "Standard Heat Loss Methodology Energy Savings Estimates," Bonneville Power Administration White Paper, April.

Schweitzer, M., M. A. Brown, and D. L. White, 1989, Electricity Savings One and Two Years After Weatherization: A Study of 1986 Participants in Bonneville's Residential Weatherization Program, ORNL/CON-289, Oak Ridge National Laboratory, Oak Ridge, Tennessee, September.

Sumi, D. and B. Coates, 1988, Longitudinal Evaluation of Energy Savings from Seattle City Light's Home Energy Loan Program, Seattle, Washington: Seattle City Light. 
U.S. Congress, 1978, National Energy Conservation Policy Act, Public Law 95-619, November 9.

U.S. Congress, 1980, Pacific Northwest Electric Power Planning and Conservation Act, Public Law 96-501, December.

Utah Energy Office, 1989, Utah Institutional Conservation Program, Fourth Phase Project Tier I Final Report, Unpublished report. 

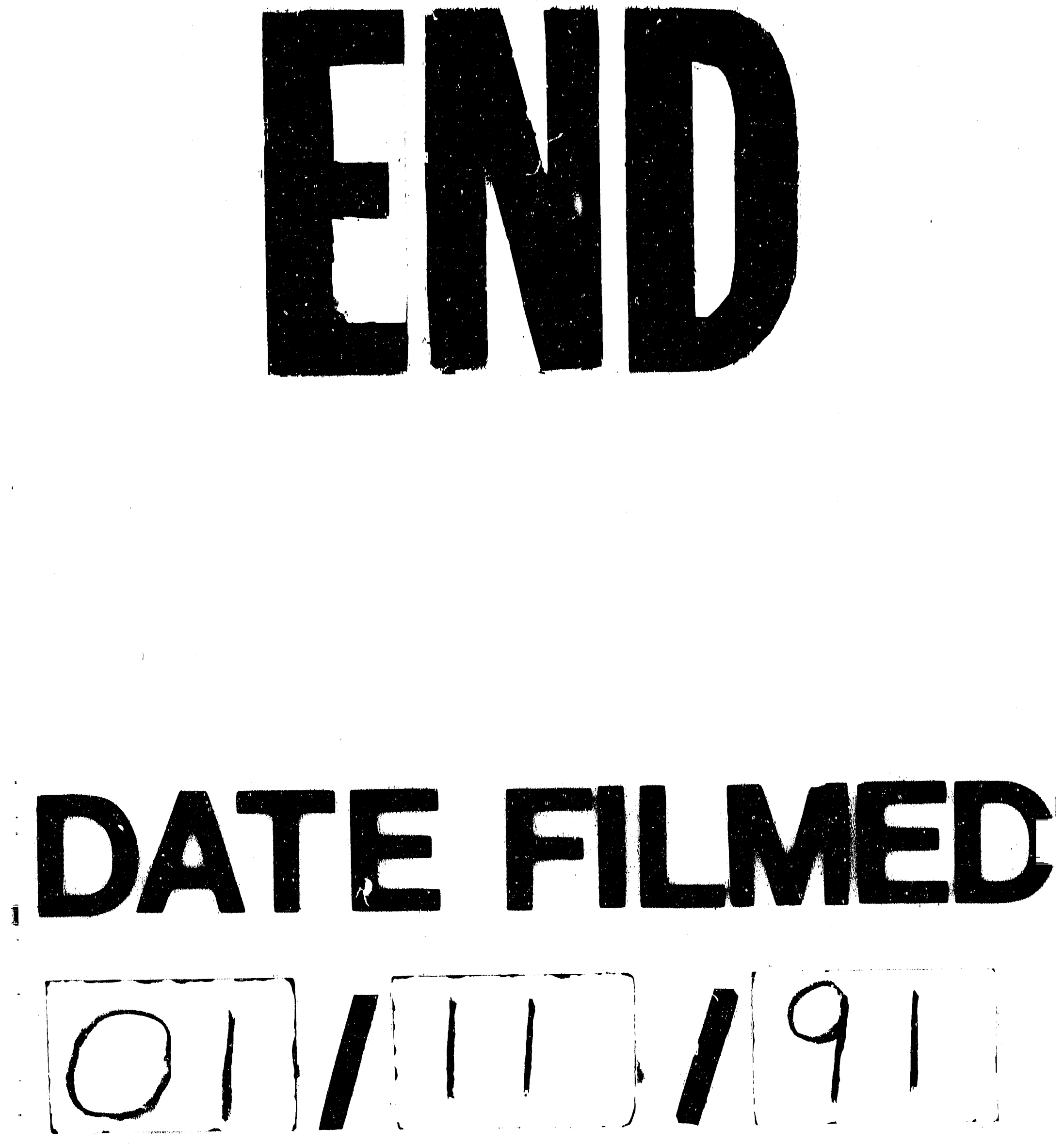
